\title{
Using Medicinal Plants in Valmalenco (Italian Alps): From Tradition to Scientific Approaches
}

\author{
Martina Bottoni ${ }^{1,2} \mathbb{D}$, Fabrizia Milani ${ }^{1,2}$, Lorenzo Colombo ${ }^{1,2}$, Kevin Nallio ${ }^{1,2} \mathbb{D}$, \\ Paola Sira Colombo ${ }^{1,2}$, Claudia Giuliani ${ }^{1,2} \mathbb{D}$, Piero Bruschi ${ }^{3}$ and Gelsomina Fico ${ }^{1,2, *}$ \\ 1 Department of Pharmaceutical Science, University of Milan, 20133 Milan, Italy; \\ martina.bottoni@unimi.it (M.B.); fabrizia.milani@unimi.it (F.M.); lorecolo.93@gmail.com (L.C.); \\ kevin.nallio@studenti.unimi.it (K.N.); pasico19@virgilio.it (P.S.C.); claudia.giuliani@unimi.it (C.G.) \\ 2 Botanical Garden G.E. Ghirardi, Department of Pharmaceutical Science, University of Milan, \\ Toscolano Maderno, 25088 Brescia, Italy \\ 3 Department of Agricultural, Environmental, Food and Forestry Science and Technology, \\ University of Florence, 50144 Florence, Italy; piero.bruschi@unifi.it \\ * Correspondence: gelsomina.fico@unimi.it
}

Received: 7 August 2020; Accepted: 4 September 2020; Published: 10 September 2020

\begin{abstract}
This ethnobotanical survey was carried out in Caspoggio (Valmalenco, SO, Italy) with the purpose of investigating the traditional uses of medicinal plants. Moreover, a bibliographic research meant to validate or refute the uses, focusing on the potentially responsible compounds, was performed. Fifty-nine species, attributable to 30 families (Asteraceae, Pinaceae, Malvaceae, and Lamiaceae the most cited), were mentioned. Arnica montana, anti-inflammatory for traumas and musculoskeletal pains; Pinus mugo, expectorant; Malva sylvestris, anti-inflammatory and soothing; Achillea moschata, digestive. The compounds, responsible for the therapeutic activities, are often polyphenols and terpenoids: helenanin in A. montana, $\alpha$-pinene, $\delta$-3-carene, and limonene in P. mugo, gossypin and malvin in M. sylvestris, luteolin and apigenin in A. moschata. Scientific evidence for at least one of the traditional activities described was found for 50 species but only in 26 out of 196 works consulted, it is possible to make a comparison between investigated extracts and traditional preparations. This study is thus a stimulus to new phytochemical investigations, mimicking as much as possible the traditional preparations. This work is part of the European Interreg Italy-Switzerland B-ICE project, aimed at creating a management model for the ongoing climate change and searching for new sources of territory valorization as attractions for tourists.
\end{abstract}

Keywords: Valmalenco; ethnobotany; traditional uses; medicinal plants; climate change

\section{Introduction}

Ethnobotany of mountain regions is receiving increased interest in recent years [1] due to the growing awareness about the impact of global warming on mountain biodiversity and the issues of conservation and sustainable management of the landscape. Mountain areas are recognized to be an important reservoir of ethnobotanical knowledge [2,3]. The high diversity of habitats and the historical isolation of the local communities have led to a strong diversification of the local cultural heritage. However, ethnobotanical knowledge is disappearing in mountain areas of many parts of the world, particularly in developed countries, due to the ongoing socio-economic changes and the loss of ethnic cultures. This process has been widely investigated, since loss of traditional knowledge could result in declining capacities of local communities to manage and conserve their ecosystems [4] and, therefore, has direct consequences on the use of biological resources by the next generations $[5,6]$. According to Dutfield [7] the erosion of ethnopharmacological knowledge and the abandonment of 
traditional practices might also involve a loss of access to a stock of bioactive compounds potentially useful for therapeutic application and drug development. As pointed out in many papers $[7,8]$, traditional knowledge may be an important source of information in synthetic drug development and in natural-product research. Several bioprospection studies aiming at investigating plant-based biologically active agents have been developed in the recent years; the first step, and one of the major challenges, is the selection of plants for pharmacological studies. According to an ethnodirected approach, candidate plants can be selected by using information collected in ethnobotanical or ethnopharmacological field researches and analyzed by using quantitative tools [9]. It should be noted that traditional know-how is only a part of a large reservoir of available knowledge [7], including database, books and journal papers; information reported by informants need to be verified and validated through a comparison with the available scientific literature $[7,8]$.

The present study is the first ethnobotanical investigation in Valmalenco (Figure 1). It is part of the European Interreg Italy-Switzerland B-ICE project, aimed at creating a management model for the ongoing climate change and searching for new opportunities of territory valorization as attractions for tourists. Specifically, our work focused on Caspoggio, a village of about 1,400 inhabitants, located at $1098 \mathrm{~m}$ above sea level, enclosed by the Bernina Alps. Situated at the border with Valtellina, in the province of Sondrio (Lombardy-Italy), Valmalenco was an important link between Italy and Switzerland due to a millenary thoroughfare that used to cross the entire valley: the 'cavallera del Muretto' road. Between the 19th and 20th centuries, alternative passes were created and that ancient road was closed, resulting in the impoverishment of the local society, economy, and territory.

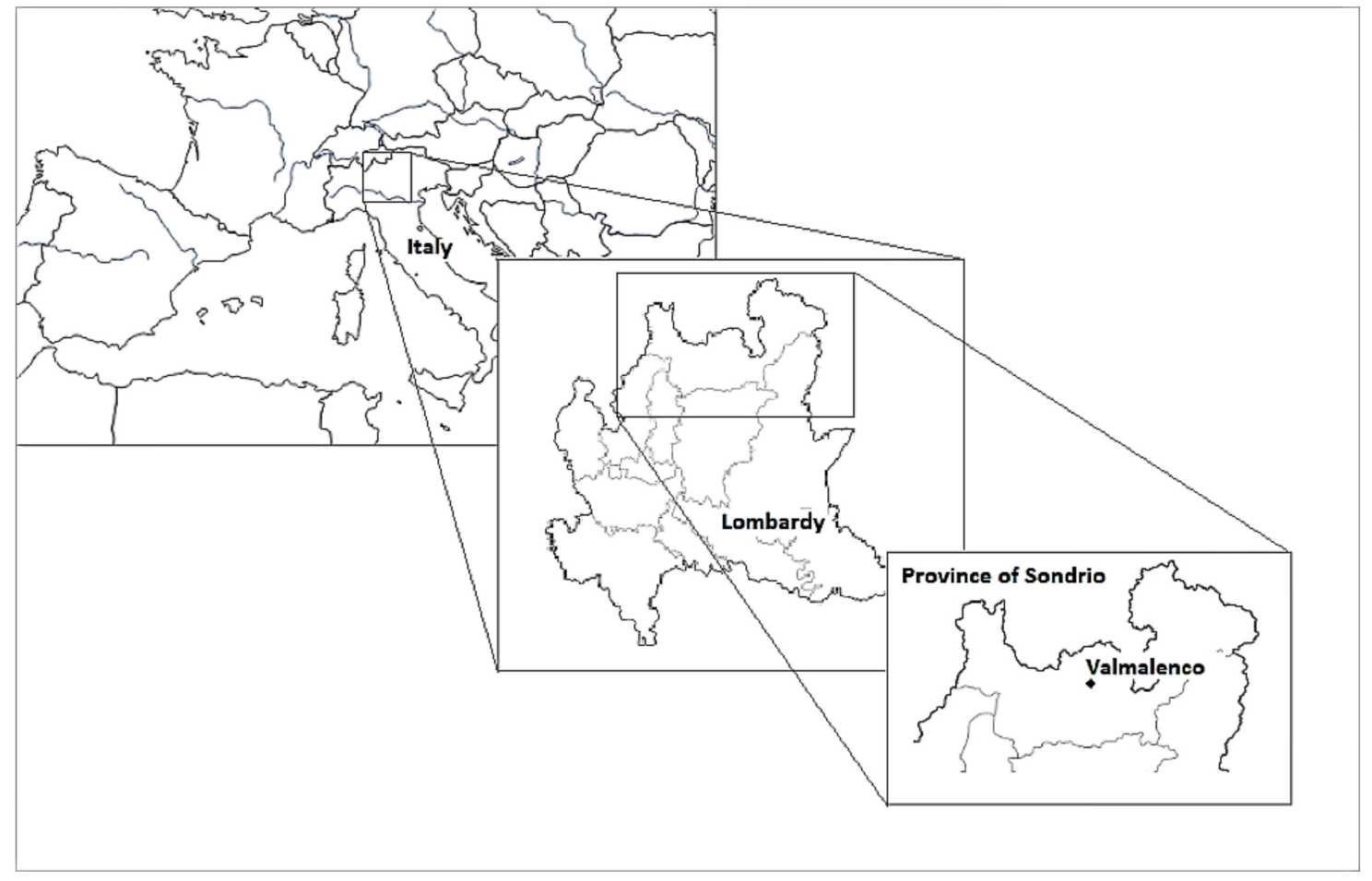

Figure 1. Geographical position of Valmalenco (SO, Italy).

This study combines ethnobotanical field research with chemical and pharmacological information reported in books and journal articles, in order to assess the pharmaceutical value of plants traditionally used by people living in Valmalenco. Furthermore, through the rediscovering and valorization of this traditional knowledge, the present study wants to provide basic information for an efficient and sustainable approach to the use of the local natural resources.

In this research we: (1) investigated the traditional uses of plant species locally used for human and animal healthcare; (2) consulted both ethnobotanical and pharmacological literature for scientific 
evidence meant to validate the traditional uses reported by the informants; (3) linked plants secondary metabolites classes to the reported biological activities.

\section{Results and Discussion}

\subsection{Field Work}

A total of 137 informants were interviewed in Caspoggio. All collected data is summarized in Table S1, providing for each cited species the family, the botanical name, the vernacular name, the used plant part and preparation, the field of use, the category of use, and the detailed use. The last three columns concern the bibliographic research carried out on the species and are thus organized: Bibliographic reference: Ethnobotany (similar traditional uses throughout Italy and the world); Bibliographic reference: Biological activity (in vitro, in vivo studies or clinical trials); Bibliographic reference: Active compounds (studies on correlation between some of the active compounds of the species and their potential biological activity described in Caspoggio).

The study provides information on 59 species (1659 citations) used for human and animal healthcare, belonging to 53 genera and 30 botanical families. Asteraceae is the most cited family (692 citations for 13 species, $41.7 \%$ of the total citations), including plants both well known in the studied area (e.g., Achillea moschata Wulfen, Arnica montana L., and Matricaria chamomilla L.) and multi-purpose plants, e.g., used in different disease categories (e.g., Achillea millefolium L.). From the literature, it is evident that Asteraceae is actually the most representative family in Valmalenco (with 46 species, $27.7 \%$ of the autochthonous species cited in a reference text concerning the spontaneous plants in the province of Sondrio [10]). Other families with a high number of citations include either fewer species (Pinaceae: 289 citations for four species; Malvaceae: 142 citations for two species) or many plants most of which were less frequently cited by informants (Labiatae with 83 citations for Thymus spp. and few citations for the others). Of the mentioned plants, 36 (61\%) were herbaceous perennials, $15(25 \%)$ woody perennials and 3 sub-shrubs (5\%). Annuals, biennials, lianas, ferns and lichens accounted for the remaining $9 \% .86 .9 \%$ of citations concerning the use of wild species and only $6.6 \%$ of cultivated species (Brassica oleracea L., Calendula officinalis L., Laurus nobilis L., Lavandula angustifolia Miller, Matricaria chamomilla, Origanum vulgare L., Rosmarinus officinalis L., Salvia officinalis L., and Solanum tuberosum L.). In $6.4 \%$ of the cases, the used species can be either wild or cultivated (Malva sylvestris L., Matricaria chamomilla, Mentha x piperita L.). The main used parts are flowers (21 species; 642 citations) and leaves (21 species; 301 citations) followed by the epigeous part $(19 ; 222)$.

The most frequently reported method of preparation is infusion (736 citations; $44 \%$ of the total citations), both for internal and external administration (oral use $71 \%$, compress $18 \%$, washing $5 \%$, footbath $1.5 \%$, other $4.5 \%$ ) followed by other preparation (e.g., the plant applied raw as poultice, exudate etc.; 376 citations; $23 \%$ of the total citations), syrup (228; $14 \%$ of the total citations), and oleolite (122; $7 \%$ of the total citations). Infusion from flowers or leaves is one of the most common methods of preparation in phytomedical practice as it is very easy to prepare and allows the extraction of a high quantity of bioactive metabolites. During our fieldwork, it was possible to acquire precious information concerning other preparations of the traditional remedies, through direct observation of the informants. As way of example, we mention the expectorant 'syrup', made through maceration in sugar of green pinecones of $P$. mugo kept in glass jars under the sun for 60 days, or the dandelion 'honey', soothing in case of sore throat, obtained after boiling the inflorescences in water and lemon juice, then covering them with sugar (Table 1). The dosage of the administered drugs and the duration of the treatment are not fixed. Rarely, the informant gave us information about the potential toxicity of some of the remedies if wrongly administered (i.e., the infusion of Achillea millefolium for stomachache and menstrual pains, when prepared with more than three flowers or drunk for more than 3 days in a row). 
Table 1. Some of the traditional preparations in the village of Caspoggio.

\begin{tabular}{|c|c|c|}
\hline Species & Preparation & Traditional Recipe \\
\hline $\begin{array}{c}\text { Arnica montana L. subsp. montana } \\
\text { Arnica }\end{array}$ & $\begin{array}{l}\text { Inflorescences } \\
\text { exudate }\end{array}$ & $\begin{array}{l}\text { Put the inflorescences in an empty glass flagon. } \\
\text { Keep it under the summer sun. Turn the flagon upside down } \\
\text { in order to help the exudate to leak from the inflorescences, } \\
\text { regularly gathering the liquid. }\end{array}$ \\
\hline Calendula officinalis L. Calendula & Macerated oil & $\begin{array}{l}\text { Fill a glass jar to the brim with inflorescences. Cover the } \\
\text { flowers with almond oil. Keep the jar under the sun for } \\
\text { 20-30 days. Filter the macerated oil. }\end{array}$ \\
\hline $\begin{array}{l}\text { Hypericum perforatum } \mathrm{L} \text {. } \\
\text { Hypericum }\end{array}$ & Macerated oil & $\begin{array}{l}\text { Fill a glass jar to the brim with inflorescences collected in } \\
\text { June-July. Cover the flowers with almond, olive, or } \\
\text { sunflower oil. Keep the jar under the summer sun. Filter the } \\
\text { macerated oil in September. }\end{array}$ \\
\hline $\begin{array}{l}\text { Larix decidua Mill. Larch } \\
\text { Picea abies (L.) H.Karst Spruce }\end{array}$ & Ointment & $\begin{array}{l}\text { Mix } 1 \mathrm{Kg} \text { of spruce and larch resin with } 100 \mathrm{~g} \text { of butter, olive } \\
\text { oil, and bee wax until it reaches a smooth texture. }\end{array}$ \\
\hline Pinus mugo Turra Mountain pine & Pinecones syrup & $\begin{array}{l}\text { Put green pinecones collected in June in a glass jar until they } \\
\text { reach the brim. Cover the pinecone completely with white } \\
\text { sugar. Keep the jar under the summer sun for } 60 \text { days, } \\
\text { shaking it at intervals. Filter the syrup. }\end{array}$ \\
\hline Taraxacum spp. Dandelion & $\begin{array}{l}\text { Inflorescences } \\
\text { syrup }\end{array}$ & $\begin{array}{l}\text { Put } 100 \text { flower heads in a glass jar and cover them with } 100 \mathrm{~g} \\
\text { of white sugar. Keep the jar under the summer sun for } 30-40 \\
\text { days, until the sugar melts. Filter the syrup. }\end{array}$ \\
\hline
\end{tabular}

Most plants (44) are used individually while a few (15) are sometimes reported to be used in mixtures (3\% of the total citations). Some examples of mixtures are: an infusion of Achillea moschata (epigeal part) and Matricaria chamomilla (flowers) to improve digestion; an infusion of Betula spp. (leaves), Fraxinus excelsior (leaves), and Urtica dioica (leaves) as diuretic and depurative of the urinary tract; an infusion of Juniperus communis (fruits), A. moschata (epigeal part), and Tilia spp. (flowers) as digestive and as sedative; an unguent of Larix decidua (resin) and Pinus mugo (resin) as anti-inflammatory and healing; an infusion of Laurus nobilis (leaves) and Salvia officinalis (leaves) as carminative; an infusion of Pinus mugo (green cones) and Achillea moschata (epigeal part) as digestive; an alcoholic macerate of Taraxacum spp. (flowers) and Gentiana lutea (roots) as digestive or a syrup of these plants against the flu; an infusion of Thymus spp. (epigeal part) and Sambucus nigra (flowers) against cough.

The traditional use of the reported plants is considered 'still relevant' in $96.6 \%$ of citations, 'uncertain' in $2.9 \%$, and 'past' in $0.2 \%$. Though in most cases these remedies are persistent nowadays, locals are aware of the declining number of individuals of some of the species. They report that the presence of the cited plants in the past was 'very frequent' in $88.7 \%$ of the cases and 'quite frequent' in $11.1 \%$, while nowadays is 'very frequent' in $60.3 \%$ and 'quite frequent' in $36.0 \%$. As way of example, the presence of Achillea moschata, Arnica montana, Artemisia genipi, and Gentiana lutea shifted from 'very frequent' in the past, to 'quite frequent' today. The last three have actually been in the list of endangered species at least since 2013, year of publication of the updated Red List of Italian Flora (Lista Rossa della Flora Italiana). Many a surveyed local people know about how harder and harder is to find A. moschata and A. genipi today due to the retreat of perennial snow and glaciers, which forces these two species to grow at higher altitudes, and to the indiscriminate collection by non-experts who, tearing their roots, jeopardize the balance of their communities.

Medicinal uses include 1613 citations (97.2\% of the total citations), pertaining to 55 species, reported by 127 informants ( $93 \%$ of all the people interviewed). The most cited plants are Arnica montana (99 informants; 294 citations), Achillea moschata (93; 124), Pinus mugo (89; 256), Malva sylvestris (63; 108), Thymus spp. $(52 ; 83)$, and Matricaria chamomilla $(48 ; 98)$. All mentioned ailments are inserted in 14 categories which, after making some adjustments to that of Economic Botany Data Collection Standard (EBDCS) [11,12], fit best with the data acquired during the fieldwork (Table 2). Half of the species (28) are used in only one (16) or two (12) categories; 19 of them are used in a number of different categories ranging from three to five. The most versatile species are Salvia officinalis, Pinus mugo, and Hypericum perforatum (six categories); Achillea millefolium (7), Achillea moschata (8), and Malva sylvestris (12). As reported in Table S1 medicinal plants are mainly used to treat digestive tract disorders 
(28 species; 297 citations), respiratory tract infections $(20 ; 348)$, general condition $(20 ; 103)$, urinary tract diseases $(20 ; 73)$, and musculoskeletal system disorders and traumas $(16 ; 410)$.

Table 2. Categories of use (pathologies treated in Caspoggio).

\begin{tabular}{|c|c|c|c|}
\hline Category of Use (Pathologies) & n. Species per Category & n. Citations per Category & ICF \\
\hline Digestive tract disorders & 28 & 297 & 0.91 \\
\hline Respiratory tract infections & 20 & 348 & 0.95 \\
\hline Urinary tract disorders & 20 & 73 & 0.74 \\
\hline Musculoskeletal system disorders and traumas & 16 & 410 & 0.96 \\
\hline Skin diseases and traumas & 14 & 140 & 0.91 \\
\hline Circulatory system disorders & 12 & 37 & 0.69 \\
\hline Gynecological disorders, obstetric and puerperal problems & 8 & 21 & 0.65 \\
\hline Ophthalmic ailments & 7 & 36 & 0.83 \\
\hline Other & 7 & 19 & 0.67 \\
\hline Oropharyngeal cavity affections & 6 & 25 & 0.79 \\
\hline Early infancy ailments & 1 & 6 & 1.00 \\
\hline
\end{tabular}

The Informant Consensus Factor (ICF) calculated for each disease category ranged from 0.65 to 1.00. As a rule, ICF values resulted to be high for uses reported by many informants, confirming that people agree on plants to be used in the treatment of common diseases. The highest values were recorded for early infancy ailments $(\mathrm{ICF}=1.00)$, followed by musculoskeletal system diseases (0.96), respiratory tract infections (0.94), digestive tract disorders, and skin diseases and traumas (0.91); the lowest values for gynecological disorders, obstetric and puerperal problems (0.65). Some of the highest agreement levels were recorded for ailments reported as the most widespread for alpine communities ([3,13-15]). All these values were higher than those observed by Vitalini et al. [13] (ICF ranging from 0.60 to 0.88$)$ and Cornara et al. [14] (0.38-0.83) but very similar to those reported by Dei Cas et al. [3] (0.80-0.92) and Vitalini et al. [15] (0.67-0.96). According to Heinrich et al. [16], informants' consensus could be useful in selecting plants for pharmacological investigations. For this purpose, we identified the species with the highest agreement among the informants (FI) in each of the categories as a further helpful piece of information. For this analysis, we included the taxa cited at least five times for a given use. The species with the highest agreement in the musculoskeletal systems diseases were Brassica oleracea (FI = 100\%; 19 citations), Arnica montana (92.9\%; 92), Hypericum perforatum $(85.7 \%$; 24), Achillea millefolium $(40.5 ; 15)$, and Pinus mugo $(26.9 \% ; 24)$. For respiratory tract infections, the species with the highest FI were Crataegus monogyna (100\%; 5) and P. mugo (100\%; 89), Sambucus nigra (91.7\%; 11), and Thymus spp. (82.7\%; 43). For digestive tract disorders: Achillea moschata (92.5\%; 86), Gentiana lutea $(89.2 ; 33)$, and Artemisia genepi $(84.6 ; 11)$. For skin diseases and traumas: Chelidonium majus (100\%; 9), Calendula officinalis $(80.9 \% ; 17)$, Larix decidua $(66.7 \% ; 10)$, and Hypericum perforatum $(46.4 \% ; 13)$. Based both on the FI values and the number of citations, other important uses in the local pharmacopoeia were Matricaria chamomilla as sedative and hypnotic $(97.9 \% ; 47)$, against abdominal pain $(41.6 \% ; 20)$ and as eyes anti-inflammatory $(31.2 \% ; 15)$, Vaccinium myrtillus to promote circulation $(83.3 \% ; 10)$ and to promote eyesight/eyes health $(75 \%$; 9), Rosa canina as laxative and to promote digestion $(75 \%$; 9$)$ and as depurative $(66.7 \% ; 8)$, Malva sylvestris for treating stomachache and to promote digestion $(52.4 \% ; 33)$ as generic anti-inflammatory $(46 \% ; 29)$, and for oropharyngeal affections $(22.2 \% ; 14)$, Plantago major for treating skin traumas $(50 \% ; 10)$.

With respect to ethnobotanical studies, 11 works concerning the alpine and pre-alpine region can be found in literature [2,3,13-15,17-22]. Only five of them were carried out in Lombardy, in valleys surrounding Valmalenco: Valvestino (BS) [19], Val San Giacomo (SO) [13], Valfurva (SO) [3], Tremezzina (CO) [17], and in the territory of Stelvio National Park (SO) [15]. These studies point out that the most used species in folk medicine are Achillea moschata, Arnica montana, Thymus pulegioides, and Artemisia genipi. A major part of the medicinal uses (71\%) recorded in these studies are specific of 
a certain area; 54 of the uses cited by informants in Caspoggio have not been previously reported in the consulted ethnobotanical literature of Italian Alpine areas and 53 of them are new for Italy (Table S1). These findings highlight how mountain areas are important hotspots of biocultural diversity and that different habitats as well as geographical factors and socio-cultural histories may deeply affect human relationships with the natural resources. Jaccard's similarity index shows values ranging from $7 \%$ (Valmalenco vs. Ligurian North Western Alps) to $27 \%$ (Valmalenco vs. Valfurva) with an average value of $13 \%$ (Table 3). There is a significant negative correlation between geographic distance and the Jaccard values (Spearman: $-0.876 ; p<0.05$ ) suggesting that villagers inhabiting areas closer to Valmalenco tend to have a similar knowledge of the use of medicinal plants. This is confirmed by a dendrogram carried out on Jaccard's similarity index showing that ethnopharmacological data from Alpine areas of Lombardy cluster together while Piedmont and Liguria Alps group in a separated cluster (Figure 2). Valvestino (VV) seems to be an exception showing the lowest similarity value (9\%) to our study area compared to the other Lombardy valleys; out of these areas, Valvestino is located at the greatest distance from Valmalenco. Based on these results it may be assumed that communities sharing ecological factors, historical backgrounds and sociocultural values have developed a similar ethnobotanical knowledge; in addition, is also possible that an exchange of ethnobotanical knowledge could have taken place, either recently or in the past, among the neighboring valleys.

Table 3. Comparison among ethnobotanical works in Alpine and Prealpine regions. Jaccard Similarity Index of medicinal plant uses (veterinary excluded) in Valmalenco (VM) and in neighboring areas. VV: Valvestino [19]; VSG: Val San Giacomo [13]; VF: Valfurva [3]; LS: Lombard Stelvio National Park [15]; WA1: Italian Western Alps [22]; WA2: Italian Western Alps [2]; NW: Italian North Western Alps [14]; VAR: Val Varaita [18]; TR: Tremezzina [17].

\begin{tabular}{ccccccc}
\hline Comparisons & $\begin{array}{c}\text { Uses Reported in } \\
\text { Both Groups }\end{array}$ & $\begin{array}{c}\text { Uses Reported in } \\
\text { One Group Only } \\
\text { (Group 1/Group 2) }\end{array}$ & $\begin{array}{c}\text { Jaccard } \\
\text { Index }\end{array}$ & Reference & $\begin{array}{c}\text { Specific } \\
\text { Uses in } \\
\text { Valmalenco }\end{array}$ \\
\hline VM & VV & 19 & $162 / 66$ & 0.09 & {$[19]$} & 162 \\
VM & VSG & 41 & $140 / 133$ & 0.18 & {$[13]$} & 140 \\
VM & VF & 69 & $112 / 209$ & 0.27 & {$[3]$} & 112 \\
VM & LS & 89 & $92 / 539$ & 0.16 & {$[15]$} & 92 \\
VM & WA1 & 17 & $164 / 53$ & 0.08 & {$[22]$} & 164 \\
VM & WA2 & 22 & $159 / 130$ & 0.08 & {$[2]$} & 159 \\
VM & NW & 24 & $157 / 198$ & 0.07 & {$[14]$} & 157 \\
VM & VAR & 15 & $166 / 38$ & 0.08 & {$[18]$} & 166 \\
VM & TR & 48 & $133 / 181$ & 0.18 & {$[17]$} & 133 \\
\hline \multicolumn{7}{r}{} \\
\end{tabular}




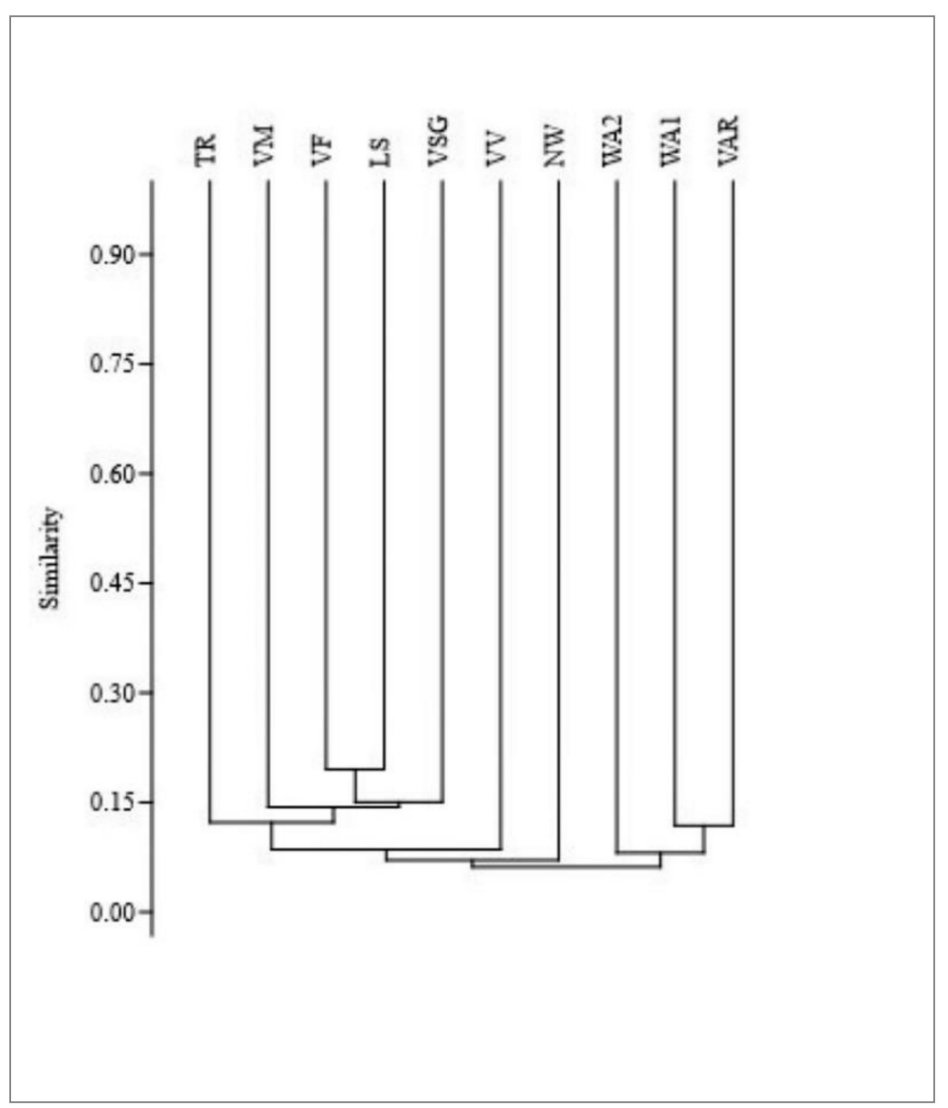

Figure 2. Cluster analysis of the medicinal plant use. Comparison among ethnobotanical works in Alpine and Prealpine regions. Traditional uses in Valmalenco (VM) and in neighboring areas. VV: Valvestino [19]; VSG: Val San Giacomo [13]; VF: Valfurva [3]; LS: Lombard Stelvio National Park [15]; WA1: Italian Western Alps [22]; WA2: Italian Western Alps [2]; NW: Italian North Western Alps [14]; VAR: Val Varaita [18]; TR: Tremezzina [17].

Veterinary uses include 46 citations ( $2.8 \%$ of the total citations), pertaining to 15 species, reported by 20 informants (1.5\% of all the informants). The amount of knowledgeable informants is rather small when compared to the 127 informants citing medicinal plants in the same community but comparable to what reported in the other studies conducted in neighboring areas $([3,15])$. We can hypothesize that ethno-veterinary knowledge in the study area was once higher, but due to changing socioeconomic and cultural values is currently disappearing, and only survives in the minds of a few informants. On the other hand, the breeders prefer to vaccinate and to treat their animals with synthetic products rather than rely on traditional herbal remedies. Four species (Carlina acaulis, Crocus vernus, Nepeta cataria, and Rumex acetosa) have only a veterinary use while the other 11 have both animal and human medicinal uses. Veterinary categories are based on the type of animals treated. The data acquired underline that eight plant species are used in cattle, four in 'other veterinary' (that includes alpacas, cats, and dogs), four are inserted in remedies for which the animal is not specified. Finally, one species is used in the treatment of pigs. The most cited uses are Carduus nutans and Carlina acaulis flowers administered as food for improving milk quality (eight citations, each), an infusion of Gentiana lutea roots to stimulate digestion in cows (five citations) and an infusion of Matricaria chamomilla flowers as anti-inflammatory for the eyes (five citations). It is important to point out that 13 of the cited veterinary uses have not been previously reported for Italy (Supplementary Materials Table S1). 


\subsection{Bibliographic Research}

A bibliographic research was performed to find a possible match between the traditional uses and the information reported in the scientific literature about the chemical composition and the pharmaceutical activity of the cited species. A total of 196 scientific papers were identified. For $84.7 \%$ of the reported species, we found scientific studies that could validate their medicinal use. However, for some species (i.e., Vaccinium myrtillus and Valeriana officinalis) we found conflicting evidence. Species with a higher number of citations, number of informants, and number of use categories in this research have more often been subjected to scientific studies (Spearman's Test: $0.456, p<0.05 ; 0.443, p<0.005$; $0.481, p<0.05)$. However, most of the medicinal species cited in Caspoggio have seldom been studied.

We present the comparison with scientific literature (for the complete data, please see Table S1): Achillea millefolium digestive, anti-inflammatory for several problems (stomachache, muscular pain, rash) and disinfectant [19,23-25]; Achillea moschata antioxidant and antibacterial [26]; Alchemilla vulgaris anti-inflammatory [27,28]; Arnica montana anti-inflammatory for wounds, cutaneous traumas, muscular, and articular pain [29-36]; Artemisia absinthium digestive [31,37-39] (however, in a review from 2016 the potential antiulcer effect, with the decrease in the production of gastric juice, is reported [40]); Artemisia genipi digestive and colds [39,41]; Betula pendula diuretic [42]; Calendula officinalis anti-inflammatory and disinfectant for wounds, rashes, and burns, improves circulation [31,43-48]; Carduus nutans antimicrobial and anti-inflammatory [49]; Cetraria islandica expectorant [50-52] and anti-inflammatory [51,53]; Chelidonium majus skin tags and warts [54,55]; Cichorium intybus depurative of the urinary tract [56,57]; Epilobium spp. anti-inflammatory [58,59], depurative of the urinary tract [59]; Equisetum arvense diuretic [60-62], anti-inflammatory for contusions [60,61,63-66], and analgesic [61,63,65]; Euphrasia officinalis eye inflammation [31,67,68]; Foeniculum vulgare anti-inflammatory, antispasmodic, and carminative [29,31,69,70]; Gentiana lutea digestive [29,31,37,71]; Hipericum perforatum soothing and anti-inflammatory for skin rashes and burns [23,31,72], muscular pain and contusions [72,73], and antidepressant [23,31,73-76]; Juniperus communis digestive [77-79]; Lamium album subsp. album diuretic [80,81]; Lavandula angustifolia anti-inflammatory and disinfectant for wounds [29,82-85], sedative [29,31,86]; Larix decidua anti-inflammatory and disinfectant for wounds and skin problems [31,87,88], antimicrobial [88]; Laurus nobilis gastroprotective [89-91] and menstrual pains [92,93]; Linum usitatissimum improves intestinal motility [94-96], expectorant, and decongestant [97]; Malva sylvestris gingivitis and inflammations of the oral cavity [98-101], demulcent, skin anti-inflammatory and regenerative [100-105], depurative of the urinary tract [106,107], and vaginal inflammation [101]; Matricaria chamomilla soothing and ocular anti-inflammatory [31,67], antispasmodic for the gastrointestinal tract $[31,43,108-110]$, and sedative [31,43,108,109,111,112]; Melissa officinalis menstrual pains [113,114]; Mentha $x$ piperita anti-inflammatory [115-117]; Origanum vulgare anti-inflammatory [118-121]; Passiflora spp. sedative hypnotic [122-126]; Plantago major anti-inflammatory and disinfectant for skin ailments [127-130], cough [127,129,130], anti-inflammatory and infections [127-129]; Picea abies gingivitis and inflammation of the oral cavity [88,131,132] and cough [31,88]; Pinus cembra cough and sore throat (antimicrobial) [133]; Pinus mugo anti-inflammatory [134], disinfectant [134], decongestant and expectorant [135,136]; Polypodium vulgare laxative [137]; Prunus avium diuretic [138]; Rosa canina diuretic and depurative of the urinary tract [139], decongestant and anti-inflammatory for sore throat [139,140]; Rosmarinus officinalis liver depurative [141-146]; Rumex alpinus disinfectant for wounds [147,148]; Salvia officinalis gingivitis [149,150], gastrointestinal bloating [150], and anti-inflammatory [150-152]; Sambucus nigra laxative [153], bronchitis, and other ailments of the upper airways [154-156]; Silybum marianum hypolipidaemic, anti-atherosclerosis [157] and hepatoprotective [23,31,157,158]; Solanum tuberosum anti-inflammatory [159-161]; Taraxacum spp. sore throat [162,163], skin inflammation [163], digestive and prokinetic [163-165], kidney problems [163,165-167], and anti-inflammatory [163,165,168]; Thymus spp. hypolipidaemic [144], balsamic and expectorant [169-172], and anti-inflammatory [170,171]; Urtica dioica hypolipidaemic, anti-atherosclerosis, hepatoprotective, and diuretic [173,174], anti-inflammatory, rheumatic pains, and contusions [65,173-176]; Vaccinium myrtillus maintenance of ocular health and 
function [146,177-184] (this last activity is refuted by a systematic review from 2004 [185]), improving of blood circulation [146,178,183,186], and maintaining of urinary tract health [187]; Vaccinium vitis-idaea maintaining of ocular health and function $[180,181]$ and maintaining of urinary tract health $[183,187,188]$; Valeriana officinalis sedative hypnotic [189-195], though a systematic review from 2015 underlined no significant variation between the valerian extract and the placebo [196].

No scientific evidence was found in literature concerning the activities emerged during the survey and the following species: Brassica oleracea (articular pain and inflammation, decongestant for upper airways), Carlina acaulis subsp. acaulis (galactagogue and throat depurative for cattles), Crocus vernus (simil intoxicated state in cats after ingestion), Fraxinus excelsior (diuretic leaves infusion); Mentha longifolia (tonic and corroborant), Oxalis acetosella (digestive); Nepeta cataria (given purposely by the mother cat to her kittens); Rumex acetosa (improves milk and its taste if given to cows); Tilia spp. (digestive, antitussive).

In accordance with the evidence, potential correlations among ethnobotanical uses of a representative species, its phytochemistry, and its pharmacological properties are discussed hereafter, with the purpose to carry out a preliminary assessment on the validation of traditional uses. The case of Pinus mugo Turra was selected based not only on its importance in Valmalenco for frequency of citations and peculiarity of its preparations, but also on the extent and relevance of information found in scientific literature.

\subsection{Pinus mugo Turra}

Traditional uses in Valmalenco attribute to Pinus mugo activities on integumentary, digestive, musculoskeletal, and respiratory systems, as well as veterinary purposes. Among the most cited properties, we found anti-inflammatory and disinfectant, especially for skin traumas or the treatment of cattle paws and hooves. Burns, frostbites, rushes, skin eruptions, and sprains are considered pathological conditions treatable with this species, in addition to activities such as digestive, expectorant, and decongestant, useful in the treatment of sore throat, cough, and colds. Different parts of the plant, as well as different ways of administration are used with the purpose of reaching the desired effects. Among the former are resin, sprouts, and cones. Among the latter, infusions, ointments, syrups, or the direct application, especially for the resin. In this regard, a peculiar use is referred in case of bones fractures: the fresh resin is melted, filtered, and applied directly on the fractured limb. Once hardened, it makes a natural plaster cast, functional if kept for 30-40 days. The inhabitants of the valley believe that the idle muscles are maintained strong and tonic by the resin, while a common plaster cast would cause their weakening.

Other ethnobotanical surveys in neighboring valleys refer to the use of the infusion of $P$. mugo as digestive, and of its syrup as expectorant $[3,13,15,19]$. From a pharmacological and phytochemical point of view, there are few studies in literature that can support this use and they all are based on characterization and evaluation of biological activity of the essential oil, often obtained from different plant matrices and from different geographic origins $[135,197,198]$.

In particular, one of the studies discusses three EO profiles, respectively obtained from needles, twigs, and cones of P. mugo, as well as their anti-inflammatory and cytotoxic activities [134].

The anti-inflammatory activity was evaluated through the quantification of IL-6 cytokine secretion by LPS-stimulated murine macrophages, while the cytotoxic effect was tested through a viability assay of three different cancer cell lines after adding the EO.

In this study, the EOs from twigs and cones of P. mugo showed a significant anti-inflammatory activity compared to the other two species of Pinus investigated, while the EOs from needles and twigs asserted a strong cytotoxic activity on cancer cells. The former activity could be attributed to the high concentration of $\alpha$-pinene in the EOs. This molecule is actually considered responsible for the inhibition of the secretion of several pro-inflammatory cytokines. Moreover, other major compounds, such as limonene and $\delta$-3-carene, could contribute to the down-regulation of neutrophil, resulting in a reduction of the inflammatory response. 
Furthermore, hydrogen peroxide, found in the EO of adult individuals of P. mugo, could help prolong the holding time of antimicrobial agents on the application site.

On the other hand, cytotoxic activity could be attribute to $\alpha$-pinene, $\beta$-pinene, germacrene $D$, and $\alpha$-terpinol. Among these, $\alpha$-pinene seems to be responsible for the antiproliferative activity on human breast cancer cell line MCF-7 [134].

In light of the above, it is thus possible to justify the beneficial effects of $P$. mugo in several ailments described in Valmalenco. Therefore, inflammatory conditions can be attributed to tissue and vascular reactions caused by skin traumas, burns, rushes, skin eruptions, and sprains that can plausibly lead to the production of inflammatory exudates, as well as heat, redness, and pain at an epithelium level.

The anti-inflammatory effect can be considered in case of skin wounds, applicable also in the veterinary fields, where a purulent exudate can lead to a responsible infective agent.

The expectorant and decongestant properties, useful against sore throat, cough, and colds, can be as well explained through the anti-inflammatory activity explicated on the upper airways mucosal membranes. Some of the studies acknowledge to the EO of $P$. mugo antimicrobial action against fungi, yeasts, gram-positive, and gram-negative bacteria [197], especially respiratory bacteria such as Klebsiella, Morganella, Staphylococcus and Escherichia [135], as well as secretolytic effects [136], which can improve the air flow through the airways.

All the EOs tested in these studies show $\delta$-3-carene and $\alpha$-pinene as major compounds to which, synergistically with minor ones, the antimicrobial activity can be supposedly ascribed.

Therefore, these effects can be involved, together with the anti-inflammatory activity, in the management of respiratory problems or skin wounds. Nevertheless, it is of utmost importance to underline that the activities described in literature are attributed to the EO obtained from the species while, in our case, the traditional preparations used are of a completely different nature.

Works such as ours gain value and importance in these observations, but they must be given prompt response by phytochemical and pharmacological studies, with the purpose of investigating traditional preparations and extracts and their potential biological activity.

No evidence was found concerning the digestive effects, nor the beneficial activity of the resin compared to the common plaster cast.

The bibliographic research highlighted that data on the composition of secondary metabolites, potentially related to biological activities, can be detected for 45 species out of 59 . For some of these, such as Achillea moschata, Artemisia absinthium, Linus usitatissimum, and Pinus mugo, there is extensive data in respect of the different extractive methods and separation techniques, while for other species the information is lacking.

It is necessary to underline that very few extracts studied in literature can be compared to the traditional preparations cited in Caspoggio (only 26 out of the 196 studies consulted, related to 18 species. For more information, please see Table 4). For this reason, it is extremely hard to make assumptions on the involvement of isolated compounds in the biological activity described.

Ultimately, for 14 species (Brassica oleracea, Carlina acaulis subsp. acaulis, Cichorium intybus, Crataegus monogyna, Crocus vernus, Fraxinus excelsior, Lamium album, Melissa officinalis, Mentha longifolia, Nepeta cataria, Oxalis acetosella, Prunus avium, Rumex acetosa and Tilia spp.) no information was found about the correlation between their chemical characterization and the biological activity to which the traditional uses can be ascribed. Some of these, such as B. oleracea (cataplasm for arthritis), C. monogyna (upper airways infections), or M. officinalis (externally applied against menstrual pains), are characterized by peculiar preparations and traditional uses that require more consideration. 
Table 4. Comparable extracts mentioned in literature with the traditional preparations.

\begin{tabular}{|c|c|c|c|c|c|c|}
\hline \multirow{2}{*}{ Latin Name } & \multicolumn{4}{|c|}{ Traditional Uses in Valmalenco } & \multirow{2}{*}{ Type of Preparation in Literature } & \multirow{2}{*}{ Reference } \\
\hline & Part of the Plant and Preparation & Field of Use & Category of Use & Detailed Use & & \\
\hline \multirow{2}{*}{$\begin{array}{c}\text { Achillea } \\
\text { millefolium } \mathrm{L} \text {. }\end{array}$} & \multirow{2}{*}{$\begin{array}{l}\text { Epigeal part (Whole) (compresses } \\
\text { with infusion) }\end{array}$} & \multirow{2}{*}{ Med } & \multirow{2}{*}{$\begin{array}{l}\text { Skin diseases and } \\
\text { traumas }\end{array}$} & \multirow{2}{*}{$\begin{array}{l}\text { Anti-inflammatory, disinfectant and } \\
\text { wound healing, Emollient, soothing }\end{array}$} & $\begin{array}{l}\text { Hot water extract with hemostyptic } \\
\text { activity in vitro }\end{array}$ & [25] \\
\hline & & & & & $\begin{array}{l}\text { Aqueous extract with anti-inflammatory } \\
\text { activity in vitro }\end{array}$ & [24] \\
\hline \multirow{2}{*}{$\begin{array}{l}\text { Matricaria } \\
\text { chamomilla } \mathrm{L} .\end{array}$} & \multirow{2}{*}{$\begin{array}{c}\text { Flowers/inflorescences/flowering } \\
\text { tops (infusion) } \\
\text { Flowers/inflorescences/flowering } \\
\text { tops (infusion) }\end{array}$} & Med & \multirow{2}{*}{$\begin{array}{l}\text { - } \\
\begin{array}{c}\text { Nervous system } \\
\text { disorders }\end{array}\end{array}$} & Anti-oxidant & $\begin{array}{l}\text { Aqueous extract with anti-oxidant } \\
\text { activity in vitro }\end{array}$ & \multirow{2}{*}{ [108] } \\
\hline & & Med & & Sedative hypnotic, promotes sleep & $\begin{array}{l}\text { Lyophilized aqueous extract with } \\
\text { activity on CNS }\end{array}$ & \\
\hline \multirow[t]{2}{*}{ Taraxacum spp. } & $\begin{array}{c}\text { Flowers/inflorescences/flowering } \\
\text { tops (infusion) } \\
\text { Leaves (infusion or decoction) } \\
\text { Epigeal part (Whole) (infusion) } \\
\text { Underground organs } \\
\text { (roots/bulbs/tubers/rhizomes) } \\
\text { (infusion or decoction) }\end{array}$ & Med & $\begin{array}{l}\text { Urinary tract } \\
\text { disorders }\end{array}$ & $\begin{array}{l}\text { Kidney stones Cystitis and other } \\
\text { inflammation of the urinary tract } \\
\text { Urinary tract depurative Diuretic }\end{array}$ & $\begin{array}{l}\text { Aqueous roots extract with diuretic } \\
\text { activity in rats }\end{array}$ & \multirow[t]{2}{*}{ [167] } \\
\hline & Leaves (infusion or decoction) & Med & - & Anti-inflammatory & $\begin{array}{l}\text { Aqueous leaves extract with } \\
\text { anti-inflammatory activity in vivo }\end{array}$ & \\
\hline $\begin{array}{l}\text { Gentiana lutea } \\
\text { L. subsp. lutea }\end{array}$ & $\begin{array}{l}\text { Underground organs } \\
\text { (roots/bulbs/tubers/rhizomes) } \\
\text { (decoction, grappa) }\end{array}$ & Med & $\begin{array}{l}\text { Digestive tract } \\
\text { disorders }\end{array}$ & $\begin{array}{c}\text { Digestive Stomach anti-inflammatory } \\
\text { Liver anti-inflammatory Stomachache } \\
\text { Vermifuge }\end{array}$ & $\begin{array}{c}\text { EtOH roots extract with choleretic } \\
\text { activity (not the Aqueous nor the MeOH } \\
\text { extracts) }\end{array}$ & $\begin{array}{c}\text { WHO } \\
\text { Monograph-Radix } \\
\text { Gentianae } \\
\text { Luinfusione [29] } \\
\end{array}$ \\
\hline \multirow[t]{2}{*}{$\begin{array}{l}\text { Hypericum } \\
\text { perforatum } \mathrm{L} \text {. }\end{array}$} & $\begin{array}{l}\text { Flowers/inflorescences/flowering } \\
\text { tops (macerated oil) }\end{array}$ & Med & $\begin{array}{l}\text { Skin diseases and } \\
\text { traumas }\end{array}$ & \multirow{2}{*}{$\begin{array}{l}\text { Sunburns, burns, frostbites, redness and } \\
\text { rash Anti-inflammatory, disinfectant and } \\
\text { wound healing Psoriasis Insect bites } \\
\text { Contusions Sprains and dislocations } \\
\text { Articular pain and inflammations } \\
\text { Muscle inflammations and pain }\end{array}$} & \multirow{2}{*}{$\begin{array}{l}\text { Different types of macerated oils active } \\
\text { on burns and wounds } \\
21 \text { macerated oil samples of } \mathrm{H} \text {. } \\
\text { (homemade or commercial) analyzed. } \\
\text { Pseudohypericin and hypericin in all } \\
\text { samples. Hyperforin in } 4 \text { samples. }\end{array}$} & \multirow[t]{2}{*}{ [72] } \\
\hline & $\begin{array}{l}\text { Flowers/inflorescences/flowering } \\
\text { tops (macerated oil) }\end{array}$ & Med & $\begin{array}{c}\text { Musculoskeletal } \\
\text { system disorders and } \\
\text { traumas }\end{array}$ & & & \\
\hline $\begin{array}{l}\text { Origanum } \\
\text { vulgare } \mathrm{L} \text {. }\end{array}$ & $\begin{array}{c}\text { Epigeal part (Whole) } \\
\text { (infusion/compresses with infusion) }\end{array}$ & Med & - & Antioxidant activity & $\begin{array}{l}\text { Antioxidant activity of hot and cold } \\
\text { water extracts }\end{array}$ & [121] \\
\hline \multirow{2}{*}{$\begin{array}{l}\text { Rosmarinus } \\
\text { officinalis L. }\end{array}$} & \multirow[t]{2}{*}{ Epigeal part (Whole) (infusion) } & \multirow[t]{2}{*}{ Med } & \multirow{2}{*}{$\begin{array}{l}\text { Digestive tract } \\
\text { disorders }\end{array}$} & \multirow[t]{2}{*}{ Liver depurative } & $\begin{array}{l}\text { Choleretic and Hepatoprotective activity } \\
\text { of aqueous extracts in rats }\end{array}$ & [141] \\
\hline & & & & & $\begin{array}{l}\text { Hepatoprotective and antioxidant } \\
\text { activity of aqueous extract in rats }\end{array}$ & [144] \\
\hline \multirow[b]{2}{*}{ Thymus spp. } & Epigeal part (Whole) (infusion) & Med & $\begin{array}{l}\text { Circulatory system } \\
\text { disorders }\end{array}$ & Blood depurative & $\begin{array}{l}\text { Hepatoprotective and antioxidant } \\
\text { activity of aqueous extract in rats }\end{array}$ & [144] \\
\hline & $\begin{array}{c}\text { Flowers/inflorescences/flowering } \\
\text { tops (infusion) } \\
\text { Leaves (infusion) } \\
\text { Epigeal part (Whole) (infusion) }\end{array}$ & Med & $\begin{array}{l}\text { Respiratory tract } \\
\text { infections }\end{array}$ & $\begin{array}{c}\text { Balsamic Cough Colds and flu } \\
\text { symptoms Expectorant, decongestant, } \\
\text { emollient }\end{array}$ & Antimicrobial activity of aqueous extract & {$[170,199]$} \\
\hline
\end{tabular}


Table 4. Cont

\begin{tabular}{|c|c|c|c|c|c|c|}
\hline \multirow{2}{*}{ Latin Name } & \multicolumn{4}{|c|}{ Traditional Uses in Valmalenco } & \multirow{2}{*}{ Type of Preparation in Literature } & \multirow{2}{*}{ Reference } \\
\hline & Part of the Plant and Preparation & Field of Use & Category of Use & Detailed Use & & \\
\hline $\begin{array}{l}\text { Laurus nobilis } \\
\text { L. }\end{array}$ & $\begin{array}{c}\text { Fruits/infructescences/accessory } \\
\text { fruits (infusion) }\end{array}$ & Med & $\begin{array}{l}\text { Digestive tract } \\
\text { disorders }\end{array}$ & $\begin{array}{l}\text { Antiacid, gastritis, acid reflux } \\
\text { Carminative Abdominal pain }\end{array}$ & $\begin{array}{l}\text { Decoction in water of fruits with } \\
\text { gastroprotective activity }\end{array}$ & [90] \\
\hline $\begin{array}{l}\text { Linum } \\
\text { usitatissimum } \\
\text { L. }\end{array}$ & $\begin{array}{l}\text { Seeds (boiled or left in water } \\
\text { overnight, then drunk) }\end{array}$ & Med & $\begin{array}{l}\text { Digestive tract } \\
\text { disorders }\end{array}$ & Laxative, intestinal motility & $\begin{array}{c}\text { Maceration in how water to extract } \\
\text { mucilages }\end{array}$ & [95] \\
\hline \multirow{2}{*}{$\begin{array}{c}\text { Malva } \\
\text { sylvestris } \mathrm{L} .\end{array}$} & $\begin{array}{l}\text { Leaves (infusion, compresses/baths } \\
\text { with infusion) }\end{array}$ & Med & - & Analgesic & $\begin{array}{l}\text { Aqueous extract with analgesic activity } \\
\text { in rats (intraperitoneal administration) }\end{array}$ & {$[100]$} \\
\hline & Leaves (infusion) & Med & $\begin{array}{l}\text { Urinary tract } \\
\text { disorders }\end{array}$ & Depurative & $\begin{array}{l}\text { Nephroprotecive activity of aqueous } \\
\text { extract of leaves and flowers }\end{array}$ & [106] \\
\hline \multirow[t]{2}{*}{ Epilobium spp. } & Leaves (infusion) & Med & General condition & Anti-inflammatory & $\begin{array}{l}\text { Aqueous extracts with activity on COX-1 } \\
\text { and COX-2 }\end{array}$ & [58] \\
\hline & & & & & $\begin{array}{l}\text { Aqueous extracts with } \\
\text { anti-inflammatory activity in vitro }\end{array}$ & [59] \\
\hline $\begin{array}{l}\text { Chelidonium } \\
\text { majus L. }\end{array}$ & Latex or sap (applied raw) & Med & $\begin{array}{l}\text { Skin diseases and } \\
\text { traumas }\end{array}$ & Skin tags and warts & $\begin{array}{l}\text { Case report: 4-years child with warts } \\
\text { treated with raw latex }\end{array}$ & [55] \\
\hline $\begin{array}{c}\text { Cetraria } \\
\text { islandica }(\mathrm{L} .) \\
\text { Ach. subsp. } \\
\text { islandica }\end{array}$ & Epigeal part (Whole) (infusion) & Med & $\begin{array}{l}\text { Respiratory tract } \\
\text { infections }\end{array}$ & $\begin{array}{l}\text { Expectorant, decongestant, } \\
\text { emollientSorethroat and hoarseness }\end{array}$ & $\begin{array}{l}\text { Anti-inflammatory activity of aqueous } \\
\text { extract in vitro }\end{array}$ & [51] \\
\hline Passiflora spp. & Epigeal part (Whole) (infusion) & Med & $\begin{array}{l}\text { Nervous system } \\
\text { disorders }\end{array}$ & Promotes sleep & $\begin{array}{l}\text { Effect of infusion on Subjective sleep } \\
\text { quality }\end{array}$ & [126] \\
\hline $\begin{array}{l}\text { Plantago major } \\
\text { L. }\end{array}$ & Leaves (washing with infusion) & Med & $\begin{array}{l}\text { Oropharyngeal cavity } \\
\text { affections }\end{array}$ & $\begin{array}{l}\text { Gingivitis, toothache, mouth ulcers and } \\
\text { abscesses }\end{array}$ & $\begin{array}{l}\text { Anti-inflammatory activity of extract in } \\
\text { deionized water in vivo }\end{array}$ & [129] \\
\hline Rosa canina $\mathrm{L}$. & $\begin{array}{c}\text { Fruits/infructescences/accessory } \\
\text { fruits (infusion) }\end{array}$ & Med & $\begin{array}{l}\text { Respiratory tract } \\
\text { infections }\end{array}$ & Decongestant Sorethroat & $\begin{array}{l}\text { Different aqueous extracts of rose hips } \\
\text { with anti-inflammatory activity }\end{array}$ & [140] \\
\hline Urtica dioica $\mathrm{L}$. & Leaves (applied as a poultice) & Med & $\begin{array}{c}\text { Musculoskeletal } \\
\text { system disorders and } \\
\text { traumas }\end{array}$ & Rheumatism, Contusions, Hematoma & $\begin{array}{c}\text { Leaves applied on thumb against } \\
\text { osteoarthritis showed anti-inflammatory } \\
\text { activity }\end{array}$ & [176] \\
\hline
\end{tabular}




\section{Materials and Methods}

The research required the following steps:

- Preliminary Investigation on the Territory and the Local Flora

The present survey was carried out in the village of Caspoggio, in the territory of Valmalenco, a tributary valley of the Valtellina, in the province of Sondrio (Lombardy, Italy). An early bibliographic research concerning the typical local species was performed through the consultation of botany textbooks focusing on the flora of the valleys of Sondrio [10]. Due to this preliminary investigation, a table containing information on the autochthonous species (family, Latin name, common name, and habitat) was produced [200]. We supported this list with a collection of images, which could be consulted by the informants, with the purpose of helping species identification.

\section{- Interview Management and Supporting Material}

Opened and semi structured interviews were conducted through a questionnaire, consisting of an "Informant Sheet" and a "Species Sheet". In particular, the "Informant Sheet" was split into two sections: the first one dedicated to the informant (personal data, location of the interview, education, and job), the second one focused on the interview (duration, number of people present, level of empathy, and any other useful notes).

The "Species Sheet" consisted of a 7-column table arranged as follows: Species (common and vernacular name), Field of use, Detailed use, Preparation form, Administration form, Part of the plant, Other information.

Each "Informant Sheet" was matched to a corresponding "Species Sheet". Both were given the same one-to-one alphanumeric identification code. The interviews were thus successively filed in chronological order.

For each species, information was organized according to the Field of use (medicinal, veterinary, etc.) and, eventually, in more detailed categories. For example, the medicinal field was divided into several categories, one for every anatomical apparatus (Digestive tract disorders, Musculoskeletal system disorders and traumas, etc.).

- Collection of Plant Material, Production of Herbarium Samples, and Photographic Archive

During the interviews and the excursions, plant material samples and traditional preparations (liquors, syrups etc.) were collected and catalogued. Plant material was dried and used for the production of herbarium samples that were archived as further support material for species identification. With the same purpose, every step of the work was documented through photographs, conveniently catalogued.

- Data Archiving and Analysis

All data obtained from the interviews were filed in a database, an Excel spreadsheet (Microsoft, Redmond, WA, USA) where each row represents a citation, defined as a single use reported for a single species by a single informant [201]. Each informant was archived with the one-to-one identification code cited above.

Citations were considered as "distinct", if differing from one another in at least one of the following properties: species, informant, category of use, part of the plant, preparation, and administration form. The standardization in the compilation of the database simplified both data browsing and statistical elaboration.

Data tables were derived from this worksheet using the program "EBTools", a collection of Visual Basic for Applications (VBA) scripts executed within the Microsoft Excel framework. The scripts are designed to perform advanced data sorting, filtering, and counting operations according to specific user requirements. 
The Informant Consensus Factor (ICF) [202] indicates the agreement degree among the informants (the closer the index is to 1 , the higher is the agreement degree) concerning the use of species for the treatment of ailments of different organ systems.

It was calculated as follows:

$$
\mathrm{ICF}=(\text { nur }-\mathrm{nt}) /(\text { nur }-1)
$$

where nur is the number of citations in each category; nt is the number of species used.

Informants' consensus on medicinal uses was calculated for each species with the Fidelity Level index (FL) reported by Friedman in 1986 [203]. It was calculated as follows:

$$
\mathrm{Fl}=\mathrm{Np} / \mathrm{N} \times 100
$$

where $\mathrm{Np}$ is the number of informants who reported the use of a species to treat a particular ailment, and $\mathrm{N}$ is the total number of informants who mentioned the plant for any other disease.

We calculated Jaccard's similarity index (JI) to compare data reported in our study with previously published data collected from neighboring areas based on presence/absence of the reported uses. We focused the analysis only on uses for human health because veterinary uses were not reported in all the other considered studies. The following formula was applied:

$$
\mathrm{JI}=\mathrm{c} /(\mathrm{a}+\mathrm{b}-\mathrm{c}) \times 100
$$

where $c$ is the number of species common to the two sites, $a$ is the number of species used only in the site $\mathrm{A}$, and $\mathrm{b}$ is the number of species used only in the site $\mathrm{B}$.

A cluster analysis was finally conducted on these data by using the PAST 3.32 software package for Microsoft Windows.

\section{Scientific Confirmation}

Finally, an ethnobotanical, pharmacological, and phytochemical bibliographic research was carried out about species used for human and animal healthcare, through search engines and online database such as PubMed, MedLine, Google Scholar, and JANE.

Concerning the ethnobotanical research, the strategy was to combine the scientific or English common name of the species and the keywords 'ethnobotany', 'ethnopharmacology', 'traditional medicine', or 'folk medicine'.

Regarding the pharmacology and phytochemistry, we paired the plant name with specific keywords concerning the category of use cited in Valmalenco (i.e., Achillea moschata digestive system, Pinus mugo respiratory system, Arnica montana musculoskeletal system) and then the specific pathology or activity (i.e., Achillea moschata digestive, Pinus mugo cough, Arnica montana anti-inflammatory, Arnica montana inflammation etc.).

We focused our attention particularly on systematic reviews and meta-analysis, when possible, or on single in vitro, in vivo, and clinical trials studies, applying no time filters. Based on this data, specific and detailed tables were produced (Table 4 and Supplementary Materials Table S1 [2,3,13-199,204-251]).

\section{Conclusions}

Documenting traditional medicinal uses can provide valuable information on locally available species which can act as potential sources of new drugs or natural products. This is particularly true in areas understudied from this perspective like the Alpine communities where our study has been carried out. Alpine regions have an environmentally complex mosaic of different habitats as well as historical and cultural peculiarities that have marked and shaped the development of a rich ethnobotanical knowledge. Through a wide survey involving 137 informants, the present investigation shows that traditional knowledge is still quite rich and alive in Valmalenco, and that medicinal plants continue to play an important role for the local communities as part of their ancient cultural heritage. 
The high number of traditional uses (67) not previously documented for Italian Alpine areas provide an evidence of this. Furthermore, the traditional use of medicinal plants cited is considered 'still relevant' in $96.6 \%$ of citations, suggesting that medicinal uses are still practiced and transmitted within the community.

Results of the pharmacological and phytochemical bibliographic research show that the scientific information for the medicinal use of the plants cited in the ethnobotanical investigation is limited. Specifically, little is found about the forms of preparation or quantities used; even when this information is available the extracts analyzed are too often very different from the typical preparations of folk medicine. Thus, it is difficult to confirm or validate traditional uses with laboratory experimentation. Moreover, some of the species reported in the present work have never been investigated from this perspective. A summary of these results is reported in Table S1 and we believe this could provide useful information on what already exists from ethnobotanical and phytochemical studies. This represents an encouragement to new investigations in this direction, meant to extend our current knowledge, with the purpose of validating ancient traditional uses.

Lastly we are convinced that a tourism valorization of the local traditional knowledge can be created and made tangible through innovative educational and leisure activities (for example, through the establishment of a botanical garden where to cultivate and to show the medicinal plants traditionally used by the local community; workshops introducing the identification of local medicinal plants or the methods of preparing creams and ointments with the herbs; treasure hunts involving children in the discovery of herbs, etc.). This approach can contribute to the safeguarding, promotion, and development of an intangible cultural heritage and at the same time represents a valuable and sustainable complement of the local touristic offering.

Supplementary Materials: The following are available online. Table S1. Bibliographic research on plants used for human and animal healthcare.

Author Contributions: Conceptualization, G.F.; Methodology, P.B. and G.F.; Validation, P.B. and G.F.; Formal analysis, M.B., F.M., L.C. and P.B.; Investigation, M.B., F.M., L.C., P.S.C., K.N. and C.G.; Resources, C.G. and G.F.; Writing-original draft preparation, M.B., F.M., L.C. and P.S.C.; Writing-review and editing, C.G., P.B. and G.F.; Validation, P.B. and G.F.; Visualization, all the authors; Supervision, G.F.; Funding acquisition, G.F. All authors have read and agreed to the published version of the manuscript.

Funding: This research was funded by the European Interreg B-ICE Italy-Switzerland project (ID. 63143) Bernina Terra Glacialis. Study and enhancement of a precious natural and cultural heritage in an open Alpine region, with innovative approaches to the future. Valmalenco (SO): study and enhancement of the plant and cultural biodiversity through an ethnobotanical survey, December 2018-December 2021.

Acknowledgments: Our thanks go to: Concetta Pugliese, Project Manager of Interreg B-ICE project and member of the ethnobotany work group; Danilo Bruseghini, Mayor of Caspoggio; Brunella Parolini, mid-mountain guide and member of the ethnobotany work group; Alfredo Dell'Agosto, geologist and mid-mountain guide; Erika and Fabrizia, of the public library of Caspoggio; Letizia, afterschool educator; each and every inhabitant of Caspoggio for their helpfulness toward our survey. A heartfelt, warmest thank you to Iole and Nello, Elena, Tom and Giulia, Bobo, Sonia and her family, Bruna, Clara, Giacomina, Firmina, Eulalia, Clelia, Letizia, Ancilla, Paolina, Roberta and Roberto, Nello, Genziana, Enrico, Primo, and Carmen, for their acceptance, generosity, and patience. We are also grateful to Leonardo Molino for revising the English text.

Conflicts of Interest: The authors declare no conflict of interest.

\section{References}

1. Bussmann, R.W. Ethnobotany of Mountain Regions: Far Eastern Europe. In Ethnobotany of the Mountain Regions of Far Eastern Europe. Ethnobotany of Mountain Regions; Batsatsashvili, K., Kikvidze, Z., Bussmann, R.W., Eds.; Springer International Publishing: Berlin, Germany, 2019.

2. Bellia, G.; Pieroni, A. Isolated, but Transnational: The Glocal Nature of Waldensian Ethnobotany, Western Alps, NW Italy. J. Ethnobiol. Ethnomed. 2015, 11, 37. [CrossRef] [PubMed]

3. Dei Cas, L.; Pugni, F.; Fico, G. Tradition of use on medicinal species in Valfurva (Sondrio, Italy). J. Ethnopharmacol. 2015, 163, 113-134. [CrossRef] [PubMed]

4. Pilgrim, S.E.; Cullen, L.C.; Smith, D.J.; Pretty, J. Ecological knowledge is lost in wealthier communities and countries? Environ. Sci. Technol. 2008, 42, 1002-1009. [CrossRef] [PubMed] 
5. da Silva, N.A.; Alves, Â.G.; Chaves, A.; de Ulysses, P.; Ramos, M.A. A biocultural approach to the use of natural resources in Northeast Brazil: A socioeconomic perspective. Acta Bot. Brasilica 2019, 33, 315-330. [CrossRef]

6. Albuquerque, U.P. Re-examining hypotheses concerning the use and knowledge of medicinal plants: A study in the Caatinga vegetation of NE Brazil. J. Ethnobiol. Ethnomed. 2006, 2, 30. [CrossRef]

7. Dutfield, G. Why traditional knowledge is important in drug discovery. Future Med. Chem. 2010, 2, 1405-1409. [CrossRef]

8. Süntar, I. Importance of ethnopharmacological studies in drug discovery: Role of medicinal plants. Phytochem. Rev. 2019. [CrossRef]

9. Andrade-Cetto, A.; Heinrich, M. From the field into the lab: Useful approaches to selecting species based on local knowledge. Front. Pharmacol. 2011, 2, 20. [CrossRef]

10. Ferranti, R. Flora Alpina di Valtellina e Valchiavenna; LYASIS EDIZIONI: Sondrio, Italy, 2005.

11. Staub, P.O.; Geck, M.S.; Weckerle, C.S.; Casu, L.; Leonti, M. Classifying diseases and remedies in ethnomedicine and ethnopharmacology. J. Ethnopharmacol. 2015, 174, 514-519. [CrossRef]

12. Cook, F.E. Economic Botanic Data Collection Standard; Prendergast, H., Ed.; Royal Botanic Gardens: Lodon, UK, 1995.

13. Vitalini, S.; Iriti, M.; Puricelli, C.; Ciuchi, D.; Segale, A.; Fico, G. Traditional knowledge on medicinal and food plants used in Val San Giacomo (Sondrio, Italy)—An alpine ethnobotanical study. J. Ethnopharmacol. 2013, 145, 517-529. [CrossRef]

14. Cornara, L.; La Rocca, A.; Terrizzano, L.; Dente, F.; Mariotti, M.G. Ethnobotanical and phytomedical knowledge in the North-Western Ligurian Alps. J. Ethnopharmacol. 2014, 155, 463-484. [CrossRef] [PubMed]

15. Vitalini, S.; Puricelli, C.; Mikerezi, I.; Iriti, M. Plants, people and traditions: Ethnobotanical survey in the Lombard Stelvio National Park and neighbouring areas (Central Alps, Italy). J. Ethnopharmacol. 2015, 173, 435-458. [CrossRef] [PubMed]

16. Heinrich, M.; Ankli, A.; Frei, B.; Weimann, C.; Sticher, O. Medicinal plants in Mexico: Healers' consensus and cultural importance. Soc. Sci. Med. 1998, 47, 1859-1871. [CrossRef]

17. Bruschi, P.; Sugni, M.; Moretti, A.; Signorini, M.A.; Fico, G. Children's versus adult's knowledge of medicinal plants: An ethnobotanical study in Tremezzina (Como, Lombardy, Italy). Braz. J. Pharmacogn. 2019, 29, 644-655. [CrossRef]

18. Pieroni, A.; Giusti, M.E. Alpine ethnobotany in Italy: Traditional knowledge of gastronomic and medicinal plants among the Occitans of the upper Varaita valley, Piedmont. J. Ethnobiol. Ethnomed. 2009, 5, 32. [CrossRef]

19. Vitalini, S.; Tomè, F.; Fico, G. Traditional uses of medicinal plants in Valvestino (Italy). J. Ethnopharmacol. 2009, 121, 106-116. [CrossRef]

20. Rivera, D.; Alcaraz, F.; Obón, C. Wild and cultivated plants used as food and medicine by the Cimbrian ethnic minority in the Alps. I Int. Symp. Med. Aromat. Nutraceutical Plants Mt. Areas 2011, 955, 31-39. [CrossRef]

21. Obón, C.; Rivera, D.; Alcaraz, F. Wild and cultivated plants used as food and medicine by the mòcheni ethnic minority in the Alps. Acta Hortic. 2012, 955, 113-118. [CrossRef]

22. Mattalia, G.; Quave, C.L.; Pieroni, A. Traditional uses of wild food and medicinal plants among Brigasc, Kyé, and Provençal communities on the Western Italian Alps. Genet.Resour.Crop. Evol. 2013, 60, 587-603. [CrossRef]

23. WHO. WHO Monographs on Selected Medicinal Plants; WHO Library Cataloguing in Publication Data: Geneva, Switzerland, 2002; Volume 2.

24. Ali, S.I.; Gopalakrishnan, B.; Venkatesalu, V. Pharmacognosy, Phytochemistry and Pharmacological Properties of Achillea millefolium L.: A Review. Phyther. Res. 2017, 31, 1140-1161. [CrossRef]

25. Applequist, W.L.; Moerman, D.E. Yarrow (Achillea millefolium L.): A Neglected Panacea? A Review of Ethnobotany, Bioactivity, and Biomedical Research1. Econ. Bot. 2011, 65, 209-225. [CrossRef]

26. Vitalini, S.; Madeo, M.; Tava, A.; Iriti, M.; Vallone, L.; Avato, P.; Cocuzza, C.; Simonetti, P.; Argentieri, M. Chemical Profile, Antioxidant and Antibacterial Activities of Achillea moschata Wulfen, an Endemic Species from the Alps. Molecules 2016, 21, 830. [CrossRef]

27. D'Agostino, M.; Dini, I.; Ramundo, E.; Senatore, F. Flavonoid glycosides of Alchemilla vulgaris L. Proc. Phytother. Res. 1998, 12, S162-S163. [CrossRef] 
28. Boroja, T.; Mihailović, V.; Katanić, J.; Pan, S.-P.; Nikles, S.; Imbimbo, P.; Monti, D.M.; Stanković, N.; Stanković, M.S.; Bauer, R. The biological activities of roots and aerial parts of Alchemilla vulgaris L. S. Afr. J. Bot. 2018, 116, 175-184. [CrossRef]

29. WHO. WHO Monographs on Selected Medicinal Plants; WHO Library Cataloguing in Publication Data: Geneva, Switzerland, 2007; Volume 3.

30. Kriplani, P.; Guarve, K.; Baghael, U.S. Arnica montana L.-A plant of healing: Review. J. Pharm. Pharmacol. 2017, 69, 925-945. [CrossRef] [PubMed]

31. Capasso, F.; Grandolini, G.; Izzo, A.A. Fitoterapia. Impiego Razionale delle Droghe Vegetali.; Springer: Berlin, Germany, 2006.

32. Sharma, S.; Arif, M.; Nirala, R.K.; Gupta, R.; Thakur, S.C. Cumulative therapeutic effects of phytochemicals in Arnica montana flower extract alleviated collagen-induced arthritis: Inhibition of both pro-inflammatory mediators and oxidative stress. J. Sci. Food Agric. 2015, 96, 1500-1510. [CrossRef] [PubMed]

33. Hall, I.H.; Starenes, C.O.; Lee, K.H.; Waddell, T.G. Mode of action of sesquiterpene lactones as anti-inflammatory agents. J. Pharm. Sci. 1980, 69, 537-543. [CrossRef] [PubMed]

34. Hall, I.H.; Lee, K.H.; Starenes, C.O.; Sumida, Y.; Wu, R.Y.; Waddell, T.G.; Cochran, J.W.; Gerhart, K.G. Anti-inflammatory activity of sesquiterpene lactones and related compounds. J. Pharm. Sci. 1979, 68, 537-542. [CrossRef] [PubMed]

35. Jeffrey, S.L.; Belcher, H.J. Use of Arnica to relieve pain after carpal-tunnel release surgery. Altern.Ther.Health Med. 2002, 8, 66-68.

36. Lyss, G.; Schmidt, T.J.; Merfort, I.; Pahl, H.L. Helenalin, an anti-inflammatory sesquiterpene lactone from Arnica, selectively inhibits transcription factor NF-кB. Biol. Chem. 1997, 378, 951-961. [CrossRef]

37. McMullen, M.K.; Whitehouse, J.M.; Whitton, P.A.; Towell, A. Bitter tastants alter gastric-phase postprandial haemodynamics. J. Ethnopharmacol. 2014, 154, 719-727. [CrossRef] [PubMed]

38. McMullen, M.K.; Whitehouse, J.M.; Towell, A. Bitters: Time for a new paradigm. Evid. Based Complement. Altern. Med. 2015, 2015, 8. [CrossRef] [PubMed]

39. Brockhoff, A.; Behrens, M.; Massarotti, A.; Appending, G.; Meyerhof, W. Broad tuning of the human bitter taste receptor hTAS2R46 to various sesquiterpene lactones, clerodane and labdane diterpenoids, strychnine, and denatonium. J. Agric. Food Chem. 2007, 55, 6236-6243. [CrossRef] [PubMed]

40. Tafti, L.D.; Shariatpanahi, S.M.; Mahdavi Damghani, M.; Javadi, B. Traditional Persian topical medications for gastrointestinal diseases. Iran. J. Basic Med. Sci. 2017, 20. [CrossRef]

41. Vouillamoz, J.F.; Carlen, C.; Taglialatela-Scafati, O.; Pollastro, F.; Appendino, G. The génépi Artemisia species. Ethnopharmacology, cultivation, phytochemistry, and bioactivity. Fitoterapia 2015, 106, 231-241. [CrossRef]

42. Rastogi, S.; Pandey, M.M.; Rawat, A.K.S. Medicinal plants of the genus Betula-Traditional uses and a phytochemical-pharmacological review. J. Ethnopharmacol. 2015, 159, 62-83. [CrossRef]

43. WHO. WHO Monographs Selected Medicinal Plants; WHO Library Cataloguing in Publication Data: Geneva, Switzerland, 1999; Volume 1.

44. Dinda, M.; Mazumdar, S.; Das, S.; Ganguly, D.; Dasgupta, U.B.; Dutta, A.; Jana, K.; Karmakar, P. The Water Fraction of Calendula officinalis Hydroethanol Extract Stimulates In Vitro and In Vivo Proliferation of Dermal Fibroblasts in Wound Healing. Phyther. Res. 2016, 30, 1696-1707. [CrossRef]

45. Fonseca, Y.M.; Catini, C.D.; Vicentini, F.T.M.C.; Nomizo, A.; Gerlach, R.F.; Fonseca, M.J.V. Protective effect of Calendula officinalis extract against UVB-induced oxidative stress in skin: Evaluation of reduced glutathione levels and matrix metalloproteinase secretion. J. Ethnopharmacol. 2010, 127, 596-601. [CrossRef]

46. Givol, O.; Kornhaber, R.; Visentin, D.; Cleary, M.; Haik, J.; Harats, M. A systematic review of Calendula officinalis extract for wound healing. Wound Repair Regen. 2019, 27, 548-561. [CrossRef]

47. Nicolaus, C.; Junghanns, S.; Hartmann, A.; Murillo, R.; Ganzera, M.; Merfort, I. In vitro studies to evaluate the wound healing properties of Calendula officinalis extracts. J. Ethnopharmacol. 2017, 196, 94-103. [CrossRef]

48. Buzzi, M.; De Freitas, F.; De Barros Winter, M. Therapeutic effectiveness of a Calendula officinalis extract in venous leg ulcer healing. J. Wound Care 2016, 25, 732-739. [CrossRef] [PubMed]

49. Orhan, I.; Deliorman-Orhan, D.; Özçelik, B. Antiviral activity and cytotoxicity of the lipophilic extracts of various edible plants and their fatty acids. Food Chem. 2009, 115, 701-705. [CrossRef]

50. Kramer, P.; Wincierz, U.; Grubler, G.; Tschakert, J.; Voelter, W.; Mayer, H. Rational approach to fractionation, isolation, and characterization of polysaccharides from the lichen Cetraria islandica. Arzneim. Forsch. Drug Res. 1995, 45, 726-731. 
51. Freysdottir, J.; Omarsdottir, S.; Ingolfsdottir, K.; Vikingsson, A.; Olafsdottir, E.S. In vitro and in vivo immunomodulating effects of traditionally-prepared extract and purified compounds from Cetraria islandica. Proc. Nutr. Soc. 2008, 67, 423-430. [CrossRef]

52. Olafsdottir, E.S.; Ingólfsdottir, K. Polysaccharides from lichens: Structural characteristics and biological activity. Planta Med. 2001, 67, 199-208. [CrossRef]

53. Kotan, E.; Alpsoy, L.; Anar, M.; Aslan, A.; Agar, G. Protective role of methanol extract of Cetraria islandica (L.) against oxidative stress and genotoxic effects of $\mathrm{AFB}(1)$ in human lymphocytes in vitro. Toxicol. Ind. Health 2011, 27, 599-605. [CrossRef]

54. Nawrot, R. Defense-related Proteins from Chelidonium majus L. as Important Components of its Latex. Curr. Protein Pept. Sci. 2017, 18, 864-880. [CrossRef]

55. Nawrot, J.; Wilk-jędrusik, M.; Nawrot, S.; Nawrot, K.; Wilk, B.; Dawid-Pać, R.; Urbańska, M.; Micek, I.; Nowak, G.; Gornowicz-porowska, J. Milky sap of greater celandine (Chelidonium majus L.) and anti-viral properties. Int. J. Environ. Res. Public Health 2020, 17, 1540. [CrossRef]

56. Jin, Y.N.; Lin, Z.J.; Zhang, B.; Bai, Y.F. Effects of chicory on serum uric acid, renal function, and GLUT9 expression in hyperuricaemic rats with renal injury and in vitro verification with cells. Evid. Based Complement. Altern. Med. 2018, 2018, 1764212. [CrossRef]

57. Emamiyan, M.Z.; Vaezi, G.; Tehranipour, M.; Shahrohkabadi, K.; Shiravi, A. Preventive effects of the aqueous extract of Cichorium intybus L. flower on ethylene glycol-induced renal calculi in rats. Avicenna J. Phytomed. 2018, 8, 170-178.

58. Granica, S.; Piwowarski, J.P.; Czerwińska, M.E.; Kiss, A.K. Phytochemistry, pharmacology and traditional uses of different Epilobium species (Onagraceae): A review. J. Ethnopharmacol. 2014, 156, 316-346. [CrossRef] [PubMed]

59. Vitalone, A.; Allkanjari, O. Epilobium spp: Pharmacology and Phytochemistry. Phyther. Res. 2018, 32, 1229-1240. [CrossRef] [PubMed]

60. Al-Snafi, A.E. The pharmacology of Equisetum arvense-A review. IOSR J. Pharm. 2017, 7, 31-42. [CrossRef]

61. Asgarpanah, J.; Roohi, E. Phytochemistry and pharmacological properties of Equisetum arvense L. J. Med. Plants Res. 2012, 6. [CrossRef]

62. Carneiro, D.M.; Freire, R.C.; de Deus Honório, T.C.; Zoghaib, I.; Cardoso, F.F.; Tresvenzol, L.M.; de Paula, J.R.; Lima Sousa, A.L.; Brandão Veiga Jardimm, P.C.; da Cunha, L.C. Randomized, Double-Blind Clinical Trial to Assess the Acute Diuretic Effect of Equisetum arvense (Field Horsetail) in Healthy Volunteers. Evid. Based Complement. Altern. Med. 2014, 2014, 1-8. [CrossRef]

63. do Monte, F.H.M.; dos Santos, J.G.; Russi, M.; Bispo Lanziotti, V.M.N.; Moreira Leal, L.K.A.; de Andrade Cunha, G.M. Antinociceptive and anti-inflammatory properties of the hydroalcoholic extract of stems from Equisetum arvense L. in mice. Pharmacol. Res. 2004, 49, 239-243. [CrossRef]

64. Dragos, D.; Gilca, M.; Gaman, L.; Vlad, A.; Iosif, L.; Stoian, I.; Lupescu, O. Phytomedicine in Joint Disorders. Nutrients 2017, 9, 70. [CrossRef]

65. Hedaya, R. Five herbs plus thiamine reduce pain and improve functional mobility in patients with pain: A pilot study. Altern. Ther. Health Med. 2017, 23, 14-19.

66. Zgrajka, W.; Turska, M.; Rajtar, G.; Majdan, M.; Parada-Turska, J. Kynurenic acid content in anti-rheumatic herbs. Ann. Agric. Environ. Med. 2013, 20, 800-802.

67. Bigagli, E.; Cinci, L.; D'Ambrosio, M.; Luceri, C. Pharmacological activities of an eye drop containing Matricaria chamomilla and Euphrasia officinalis extracts in UVB-induced oxidative stress and inflammation of human corneal cells. J. Photochem. Photobiol. B Biol. 2017, 173, 618-625. [CrossRef]

68. Paduch, R.; Woźniak, A.; Niedziela, P.; Rejdak, R. Assessment of Eyebright (Euphrasia Officinalis L.) Extract Activity in Relation to Human Corneal Cells Using In Vitro Tests. Balkan Med. J. 2014, 33, 29-36. [CrossRef] [PubMed]

69. Badgujar, S.B.; Patel, V.V.; Bandivdekar, A.H. Foeniculum vulgare Mill: A Review of Its Botany, Phytochemistry, Pharmacology, Contemporary Application, and Toxicology. Biomed. Res. Int. 2014, 2014, 1-32. [CrossRef] [PubMed]

70. Portincasa, P.; Bonfrate, L.; Scribano, M.L.; Kohn, A.; Caporaso, N.; Festi, D.; Campanale, M.C.; Di Rienzo, T.; Guarino, M.; Taddia, M.; et al. Curcumin and fennel essential oil improve symptoms and quality of life in patients with irritable bowel syndrome. J. Gastrointest. Liver Dis. 2016, 25, 151-157. [CrossRef] [PubMed] 
71. Niiho, Y.; Yamazaki, T.; Nakajima, Y.; Yamamoto, T.; Ando, H.; Hirai, Y.; Toriizuka, K.; Ida, Y. Gastroprotective effects of bitter principles isolated from Gentian root and Swertia herb on experimentally-induced gastric lesions in rats. J. Nat. Med. 2006, 60, 82-88. [CrossRef]

72. Wölfle, U.; Seelinger, G.; Schempp, C.M. Topical application of St John's wort (Hypericum perforatum). Planta Med. 2014, 80, 109-120.

73. Uslusoy, F.; Nazıroğlu, M.; Övey, İ.S.; Sönmez, T.T. Hypericum perforatum L. supplementation protects sciatic nerve injury-induced apoptotic, inflammatory and oxidative damage to muscle, blood and brain in rats. $J$. Pharm. Pharmacol. 2019, 71, 83-92. [CrossRef]

74. Di Pierro, F.; Risso, P.; Settembre, R. Role in depression of a multi-fractionated versus a conventional Hypericum perforatum extract. Panminerva Med. 2018, 60. [CrossRef]

75. Eatemadnia, A.; Ansari, S.; Abedi, P.; Najar, S. The effect of Hypericum perforatum on postmenopausal symptoms and depression: A randomized controlled trial. Complement. Ther. Med. 2019, 45, 109-113. [CrossRef] [PubMed]

76. Ng, Q.X.; Venkatanarayanan, N.; Ho, C.Y.X. Clinical use of Hypericum perforatum (St John's wort) in depression: A meta-analysis. J. Affect. Disord. 2017, 210, 211-221. [CrossRef]

77. Majewska, E.; Kozłowska, M.; Kowalska, D.; Gruczyńska, E. Characterization of the essential oil from cone-berries of Juniperus communis L. (Cupressaceae). Herba Pol. 2017, 63, 48-55. [CrossRef]

78. Raina, R.; Verma, P.K.; Peshin, R.; Kour, H. Potential of Juniperus communis L as a nutraceutical in human and veterinary medicine. Heliyon 2019, 5, e02376. [CrossRef] [PubMed]

79. Kılıç, Ö.; Kocak, A. Volatile Constituents of Juniperus communis L., Taxus canadensis Marshall. and Tsuga canadensis (L.) Carr. from Canada. J. Agric. Sci. Technol. B 2014, 4, 135-140.

80. Bahmani, M.; Zargaran, A. Ethno-botanical medicines used for urinary stones in the Urmia, Northwest Iran. Eur. J. Integr. Med. 2015, 7, 657-662. [CrossRef]

81. Matkowski, A.; Piotrowska, M. Antioxidant and free radical scavenging activities of some medicinal plants from the Lamiaceae. Fitoterapia 2006, 77, 346-353. [CrossRef] [PubMed]

82. Cardia, G.F.E.; Silva-Filho, S.E.; Silva, E.L.; Uchida, N.S.; Cavalcante, H.A.O.; Cassarotti, L.L.; Salvadego, V.E.C.; Spironello, R.A.; Bersani-Amado, C.A.; Cuman, R.K.N. Effect of Lavender (Lavandula angustifolia) Essential Oil on Acute Inflammatory Response. Evid. Based Complement. Altern. Med. 2018, 2018, 1-10. [CrossRef] [PubMed]

83. Carrasco, A.; Martinez-Gutierrez, R.; Tomas, V.; Tudela, J. Lavandula angustifolia and Lavandula latifolia Essential Oils from Spain: Aromatic Profile and Bioactivities. Planta Med. 2015, 82, 163-170. [CrossRef]

84. Giovannini, D.; Gismondi, A.; Basso, A.; Canuti, L.; Braglia, R.; Canini, A.; Mariani, F.; Cappelli, G. Lavandula angustifolia Mill. Essential oil exerts antibacterial and anti-inflammatory effect in macrophage mediated immune response to Staphylococcus aureus. Immunol. Investig. 2016, 45, 11-28. [CrossRef]

85. Tagreed Altaei, D. Topical lavender oil for the treatment of recurrent aphthous ulceration. Am. J. Dent. 2012, 25, 39-43.

86. Nasiri Lari, Z.; Hajimonfarednejad, M.; Riasatian, M.; Abolhassanzadeh, Z.; Iraji, A.; Vojoud, M.; Heydari, M.; Shams, M. Efficacy of inhaled Lavandula angustifolia Mill. Essential oil on sleep quality, quality of life and metabolic control in patients with diabetes mellitus type II and insomnia. J. Ethnopharmacol. 2020, 251, 112560. [CrossRef]

87. Pferschy-Wenzig, E.M.; Kunert, O.; Presser, A.; Bauer, R. In Vitro Anti-inflammatory Activity of Larch (Larix decidua L.) Sawdust. J. Agric. Food Chem. 2008, 56, 11688-11693. [CrossRef]

88. Salem, M.Z.M.; Elansary, H.O.; Elkelish, A.A.; Zeidler, A.; Ali, H.M.; Hefny, M.E.L.; Yessoufou, K. In vitro bioactivity and antimicrobial activity of Picea abies and Larix decidua wood and bark extracts. BioResources 2016, 11, 9421-9437. [CrossRef]

89. Afifi, F.U.; Khalil, E.; Tamimi, S.O.; Disi, A. Evaluation of the gastroprotective effect of Laurus nobilis seeds on ethanol induced gastric ulcer in rats. J. Ethnopharmacol. 1997, 58, 9-14. [CrossRef]

90. Gürbüz, İ.; Üstün, O.; Yeşilada, E.; Sezik, E.; Akyürek, N. In vivo gastroprotective effects of five Turkish folk remedies against ethanol-induced lesions. J. Ethnopharmacol. 2002, 83, 241-244. [CrossRef]

91. Speroni, E.; Cervellati, R.; Dall'Acqua, S.; Guerra, M.C.; Greco, E.; Govoni, P.; Innocenti, G. Gastroprotective effect and antioxidant properties of different Laurus nobilis L. leaf extracts. J. Med. Food 2011, 14, 499-504. [CrossRef] [PubMed] 
92. Motti, R.; Bonanomi, G.; Emrick, S.; Lanzotti, V. Traditional Herbal Remedies Used in women's Health Care in Italy: A Review. Hum. Ecol. 2019, 47, 941-972. [CrossRef]

93. Patrakar, R.; Mansuriya, M.; Patil, P. Phytochemical and Pharmacological Review on Laurus nobilis. Int. J. Pharm. Chem. Sci. 2012, 1, 595-602.

94. Xu, J.; Zhou, X.; Chen, C.; Deng, Q.; Huang, Q.; Yang, J.; Yang, N.; Huang, F. Laxative effects of partially defatted flaxseed meal on normal and experimental constipated mice. BMC Complement. Altern. Med. 2012, 12. [CrossRef]

95. Hanif Palla, A.; Gilani, A.-H. Dual effectiveness of Flaxseed in constipation and diarrhea: Possible mechanism. J. Ethnopharmacol. 2015, 169, 60-68. [CrossRef]

96. European Medicine Agency. Available online: https://www.ema.europa.eu/en/documents/herbal-summary/ linseed-summary-public_en.pdf (accessed on 5 February 2020).

97. Saadat, S.; Shakeri, F.; Boskabady, M.H. Comparative Antitussive Effects of Medicinal Plants and Their Constituents. Altern. Ther. 2018, 24, 36-49.

98. Benso, B.; Rosalen, P.L.; Alencar, S.M.; Murata, R.M. Malva sylvestris Inhibits Inflammatory Response in Oral Human Cells. An In Vitro Infection Model. PLoS ONE 2015, 10, e0140331. [CrossRef]

99. Braga, A.S.; Pires, J.G.; Magalhães, A.C. Effect of a mouthrinse containing Malva sylvestris on the viability and activity of microcosm biofilm and on enamel demineralization compared to known antimicrobials mouthrinses. Biofouling 2018, 34, 252-261. [CrossRef] [PubMed]

100. Gasparetto, J.C.; Martins, C.A.F.; Hayashi, S.S.; Otuky, M.F.; Pontarolo, R. Ethnobotanical and scientific aspects of Malva sylvestris L.: A millennial herbal medicine. J. Pharm. Pharmacol. 2012, 64, 172-189. [CrossRef] [PubMed]

101. Martins, C.; Campos, M.; Irioda, A.; Stremel, D.; Trindade, A.; Pontarolo, R. Anti-Inflammatory Effect of Malva sylvestris, Sida cordifolia, and Pelargonium graveolens Is Related to Inhibition of Prostanoid Production. Molecules 2017, 22, 1883. [CrossRef] [PubMed]

102. Fahimi, S.; Abdollahi, M.; Mortazavi, S.A.; Hajimehdipoor, H.; Abdolghaffari, A.H.; Rezvanfar, M.A. Wound Healing Activity of a Traditionally Used Poly Herbal Product in a Burn Wound Model in Rats. Iran. Red Crescent Med. J. 2015, 17. [CrossRef] [PubMed]

103. Pirbalouti, A.G.; Shahrzad, A.; Abed, K.; Hamedi, B. Wound healing activity of Malva sylvestris and Punica granatum in alloxan-induced diabetic rats. Acta Pol. Pharm. Drug Res. 2010, 67, 511-516.

104. Prudente, A.S.; Sponchiado, G.; Mendes, D.A.G.B.; Soley, B.S.; Cabrini, D.A.; Otuki, M.F. Pre-clinical efficacy assessment of Malva sylvestris on chronic skin inflammation. Biomed. Pharmacother. 2017, 93, 852-860. [CrossRef]

105. Prudente, A.S.; Loddi, A.M.V.; Duarte, M.R.; Santos, A.R.S.; Pochapski, M.T.; Pizzolatti, M.G.; Hayashi, S.S.; Campos, F.R.; Pontarolo, R.; Santos, F.A.; et al. Pre-clinical Anti-Inflammatory Aspects of a Cuisine and Medicinal Millennial Herb: Malva sylvestris L. Food Chem. Toxicol. 2013, 58, 324-331. [CrossRef]

106. Marouane, W.; Soussi, A.; Murat, J.-C.; Bezzine, S.; El Feki, A. The protective effect of Malva sylvestris on rat kidney damaged by vanadium. Lipids Health Dis. 2011, 10, 65. [CrossRef]

107. Mohamadi Yarijani, Z.; Najafi, H.; Shackebaei, D.; Madani, S.H.; Modarresi, M.; Jassemi, S.V. Amelioration of renal and hepatic function, oxidative stress, inflammation and histopathologic damages by Malva sylvestris extract in gentamicin induced renal toxicity. Biomed. Pharmacother. 2019, 112, 108635. [CrossRef]

108. McKay, D.L.; Blumberg, J.B. A Review of the bioactivity and potential health benefits of chamomile tea (Matricaria recutita L.). Phyther. Res. 2006, 20, 519-530. [CrossRef]

109. Miraj, S.; Alesaeidi, S. A systematic review study of therapeutic effects of Matricaria recuitta chamomile (chamomile). Electron. Physician 2016, 8, 3024-3031. [CrossRef] [PubMed]

110. Mehmood, M.H.; Munir, S.; Khalid, U.A.; Asrar, M.; Gilani, A.H. Antidiarrhoeal, antisecretory and antispasmodic activities of Matricaria chamomilla are mediated predominantly through $\mathrm{K}+$-channels activation. BMC Complement. Altern. Med. 2015, 15, 1-9. [CrossRef] [PubMed]

111. Keefe, J.R.; Mao, J.J.; Soeller, I.; Li, Q.S.; Amsterdam, J.D. Short-term open-label chamomile (Matricaria chamomilla L.) therapy of moderate to severe generalized anxiety disorder. Phytomedicine 2016, 23, 1699-1705. [CrossRef] [PubMed]

112. Mao, J.J.; Xie, S.X.; Keefe, J.R.; Soeller, I.; Li, Q.S.; Amsterdam, J.D. Long-term chamomile (Matricaria chamomilla L.) treatment for generalized anxiety disorder: A randomized clinical trial. Phytomedicine 2016, 23, 1735-1742. [CrossRef] 
113. Akbarzadeh, M.; Dehghani, M.; Moshfeghy, Z.; Emamghoreishi, M.; Tavakoli, P.; Zare, N. Effect of Melissa officinalis Capsule on the Intensity of Premenstrual Syndrome Symptoms in High School Girl Students. Nurs. Midwifery Stud. 2015, 4, 24-28. [CrossRef]

114. Mirabi, P.; Namdari, M.; Alamolhoda, S.H.; Mojab, F. The effect of Melissa officinalis extract on the severity of primary dysmenorrhea. Iran. J. Pharm. Res. 2017, 16, 171-177. [CrossRef]

115. Atta, A.H.; Alkofahi, A. Anti-nociceptive and anti-inflammatory effects of some Jordanian medicinal plant extracts. J. Ethnopharmacol. 1998, 60, 117-124. [CrossRef]

116. Sun, Z.; Wang, H.; Wang, J.; Zhou, L.; Yang, P. Chemical Composition and Anti-Inflammatory, Cytotoxic and Antioxidant Activities of Essential Oil from Leaves of Mentha piperita Grown in China. PLoS ONE 2014, 9 , e114767. [CrossRef]

117. Li, Y.X.; Liu, Y.B.; Ma, A.Q.; Bao, Y.; Wang, M.; Sun, Z.L. In vitro antiviral, anti-inflammatory, and antioxidant activities of the ethanol extract of Mentha piperita L. Food Sci. Biotechnol. 2017, 26, 1675-1683. [CrossRef]

118. Silva, F.V.; Guimarães, A.G.; Silva, E.R.S.; Sousa-Neto, B.P.; MacHado, F.D.F.; Quintans-Júnior, L.J.; Arcanjo, D.D.R.; Oliveira, F.A.; Oliveira, R.C.M. Anti-Inflammatory and Anti-Ulcer Activities of Carvacrol, a Monoterpene Present in the Essential Oil of Oregano. J. Med. Food 2012, 15, 984-991. [CrossRef]

119. Xiao, Y.; Li, B.; Liu, J.; Ma, X. Carvacrol ameliorates inflammatory response in interleukin $1 \beta$-stimulated human chondrocytes. Mol. Med. Rep. 2017, 17, 3987-3992. [CrossRef] [PubMed]

120. Naquvi, K.J.; Ahamad, J.; Salma, A.; Ansari, S.H.; Najmi, A.K. A critical review on traditional uses, phytochemistry, and pharmacological uses of Origanum vulgare Linn. Int. Res. J. Pharm. 2019, 10, 7-11. [CrossRef]

121. Singh, P.; Kothiyal, P.; Ratan, P. Pharmacological and Phytochemical Studies of Origanum vulgare: A Review. Int. Res. J. Pharm. 2018, 9, 30-34. [CrossRef]

122. Guerrero, F.A.; Medina, G.M. Effect of a medicinal plant (Passiflora incarnata L) on sleep. Sleep Sci. 2017, 10, 96-100. [CrossRef]

123. Kim, G.; Kim, Y.; Yoon, S.; Kim, S.; Yi, S.S. Sleep-inducing effect of Passiflora incarnata L. extract by single and repeated oral administration in rodent animals. Food Sci. Nutr. 2020, 8, 557-566. [CrossRef]

124. Kim, M.; Lim, H.-S.; Lee, H.-H.; Kim, T.-H. Role Identification of Passiflora incarnata Linnaeus: A Mini Review. J. Menopausal Med. 2017, 23, 156. [CrossRef]

125. Miroddi, M.; Calapai, G.; Navarra, M.; Minciullo, P.L.; Gangemi, S. Passiflora incarnata L.: Ethnopharmacology, clinical application, safety and evaluation of clinical trials. J. Ethnopharmacol. 2013, 150, 791-804. [CrossRef]

126. Ngan, A.; Conduit, R. A double-blind, placebo-controlled investigation of the effects of Passiflora incarnata (passionflower) herbal tea on subjective sleep quality. Phyther. Res. 2011, 25, 1153-1159. [CrossRef]

127. Haddadian, K.K.; Haddadian, K.K.; Zahmatkash, M. A review of Plantago plant. Indian J. Tradit Know 2014, 13,5 .

128. Miraj, S. A review study of pharmacological properties of Plantago major 1. Der Pharma Chem. 2016, 8, 21-25.

129. Adom, M.B.; Taher, M.; Mutalabisin, M.F.; Amri, M.S.; Abdul Kudos, M.B.; Wan Sulaiman, M.W.A.; Sengupta, P.; Susanti, D. Chemical constituents and medical benefits of Plantago major. Biomed. Pharmacother. 2017, 96, 348-360. [CrossRef] [PubMed]

130. Najafian, Y.; Hamedi, S.S.; Kaboli Farshchi, M.; Feyzabadi, Z. Plantago major in Traditional Persian Medicine and modern phytotherapy: A narrative review. Electron. Physician 2018, 10, 6390-6399. [CrossRef] [PubMed]

131. Fyhrquist, P.; Virjamo, V.; Hiltunen, E.; Julkunen-Tiitto, R. Epidihydropinidine, the main piperidine alkaloid compound of Norway spruce (Picea abies) shows promising antibacterial and anti-Candida activity. Fitoterapia 2017, 117, 138-146. [CrossRef] [PubMed]

132. Tunón, H.; Olavsdotter, C.; Bohlin, L. Evaluation of anti-inflammatory activity of some Swedish medicinal plants. Inhibition of prostaglandin biosynthesis and PAF-induced exocytosis. J. Ethnopharmacol. 1995, 48, 61-76. [CrossRef]

133. Apetrei, C.L.; Tuchilus, C.; Aprotosoaie, A.C.; Oprea, A.; Malterud, K.E.; Miron, A.; Aprotosaie, A.C.; Oprea, A.; Malterud, K.E.; Miron, A. Chemical, Antioxidant and Antimicrobial Investigations of Pinus cembra L. Bark and Needles. Molecules 2011, 16, 7773-7788. [CrossRef]

134. Basholli-Salihu, M.; Schuster, R.; Hajdari, A.; Mulla, D.; Viernstein, H.; Mustafa, B.; Mueller, M. Phytochemical composition, anti-inflammatory activity and cytotoxic effects of essential oils from three Pinus spp. Pharm. Biol. 2017, 55, 1553-1560. [CrossRef] 
135. Mitić, Z.S.; Jovanović, B.; Jovanović, S.Č.; Mihajilov-Krstev, T.; Stojanović-Radić, Z.Z.; Cvetković, V.J.; Mitrović, T.L.; Marin, P.D.; Zlatković, B.K.; Stojanović, G.S. Comparative study of the essential oils of four Pinus species: Chemical composition, antimicrobial and insect larvicidal activity. Ind. Crops Prod. 2018, 111, 55-62. [CrossRef]

136. Ciuman, R.R. Phytotherapeutic and naturopathic adjuvant therapies in otorhinolaryngology. Eur. Arch. Oto Rhino Laryngology 2012, 269, 389-397. [CrossRef]

137. European Medicines Agency Evaluation of Medicines for Human Use. EMEA Assessment Report on Polypodium vulgare L., RHIZOMA; European Medicines Agency: London, UK, 2008.

138. Hooman, N.; Mojab, F.; Nickavar, B.; Pouryousefi-Kermani, P. Diuretic effect of powdered Cerasus avium (cherry) tails on healthy volunteers. Pak. J. Pharm. Sci. 2009, 22, 381-383.

139. Selahvarzian, A.; Alizadeh, A.; Baharvand, P.A.; Eldahshan, O.A.; Rasoulian, B. Medicinal Properties of Rosa canina L. Herb. Med. J. 2018, 3, 77-84. [CrossRef]

140. Winther, K.; Campbell-Tofte, J.; Vinther Hansen, A.S. Bioactive ingredients of rose hips (Rosa canina L.) with special reference to antioxidative and anti-inflammatory properties: In vitro studies. Bot. Targets Ther. 2016, 6, 11-23. [CrossRef]

141. Al-Sereiti, M.R.; Abu-Amer, K.M.; Sen, P. Pharmacology of rosemary (Rosmarinus officinalis Linn.) and its therapeutic potentials. Indian J. Exp. Biol. 1999, 37, 124-130. [PubMed]

142. Rašković, A.; Milanović, I.; Pavlović, N.; Ćebović, T.; Vukmirović, S.; Mikov, M. Antioxidant activity of rosemary (Rosmarinus officinalis L.) essential oil and its hepatoprotective potential. BMC Complement. Altern. Med. 2014, 14. [CrossRef]

143. Hassani, F.V.; Shirani, K.; Hosseinzadeh, H. Rosemary (Rosmarinus officinalis) as a potential therapeutic plant in metabolic syndrome: A review. Naunyn. Schmiedebergs. Arch. Pharmacol. 2016, 389, 931-949. [CrossRef]

144. Hegazy, A.M.; Abdel-Azeem, A.S.; Zeidan, H.M.; Ibrahim, K.S.; El Sayed, E.M. Hypolipidemic and hepatoprotective activities of rosemary and thyme in gentamicin-treated rats. Hum. Exp. Toxicol. 2018, 37, 420-430. [CrossRef] [PubMed]

145. Martínez-Rodríguez, J.L.; Gutiérrez-Hernández, R.; Reyes-Estrada, C.A.; Granados-López, A.J.; Pérez-Veyna, O.; Arcos-Ortega, T.; López, J.A. Hepatoprotective, antihyperlipidemic and radical scavenging activity of hawthorn (Crataegus oxyacantha) and rosemary (Rosmarinus officinalis) on alcoholic liver disease. Altern. Ther. Health Med. 2019, 25, 54-63.

146. WHO. WHO Monographs on Selected Medicinal Plants; WHO Library Cataloguing in Publication Data: Geneva, Switzerland, 2009; Volume 4.

147. Ozturk, S.; Ozturk, A. Antibacterial Activity of Aqueous and Methanol Extracts of Rumex alpinus and Rumex caucasicus. Pharm. Biol. 2007, 45, 83-87. [CrossRef]

148. Mishra, A.P.; Sharifi-Rad, M.; Shariati, M.A.; Mabkhot, Y.N.; Al-Showiman, S.S.; Rauf, A.; Salehi, B.; Župunski, M.; Sharifi-Rad, M.; Gusain, P.; et al. Bioactive compounds and health benefits of edible Rumex species-A review. Cell. Mol. Biol. 2018, 64, 27-34. [CrossRef]

149. Ehrnhöfer-Ressler, M.M.; Fricke, K.; Pignitter, M.; Walker, J.M.; Walker, J.; Rychlik, M.; Somoza, V. Identification of 1,8-Cineole, Borneol, Camphor, and Thujone as Anti-inflammatory Compounds in a Salvia officinalis L. Infusion Using Human Gingival Fibroblasts. J. Agric. Food Chem. 2013, 61, 3451-3459. [CrossRef]

150. Lemle, K.L. Salvia officinalis used in pharmaceutics. Proc. IOP Conf. Ser. Mater. Sci. Eng. 2018, $294,012037$. [CrossRef]

151. Jakovljević, M.; Jokić, S.; Molnar, M.; Jašić, M.; Babić, J.; Jukić, H.; Banjari, I. Bioactive Profile of Various Salvia officinalis L. Preparations. Plants 2019, 8, 55. [CrossRef]

152. Ghorbani, A.; Esmaeilizadeh, M. Pharmacological properties of Salvia officinalis and its components. J. Tradit. Complement. Med. 2017, 7, 433-440. [CrossRef] [PubMed]

153. Picon, P.D.; Picon, R.V.; Costa, A.F.; Sander, G.B.; Amaral, K.M.; Aboy, A.L.; Henriques, A.T. Randomized clinical trial of a phytotherapic compound containing Pimpinella anisum, Foeniculum vulgare, Sambucus nigra, and Cassia augustifolia for chronic constipation. BMC Complement. Altern. Med. 2010, 10, 17. [CrossRef]

154. Chen, C.; Zuckerman, D.M.; Brantley, S.; Sharpe, M.; Childress, K.; Hoiczyk, E.; Pendleton, A.R. Sambucus nigra extracts inhibit infectious bronchitis virus at an early point during replication. BMC Vet. Res. 2014, 10, 12. [CrossRef]

155. Porter, R.S.; Bode, R.F. A Review of the Antiviral Properties of Black Elder (Sambucus nigra L.) Products: Antiviral Properties of Black Elder (Sambucus nigra L.). Phyther. Res. 2017, 31, 533-554. [CrossRef] [PubMed] 
156. Hawkins, J.; Baker, C.; Cherry, L.; Dunne, E. Black elderberry (Sambucus nigra) supplementation effectively treats upper respiratory sympoms: A meta-analysis of randomized, controlled clinical trials. Complement. Ther. Med. 2019, 42, 361-365. [CrossRef]

157. Bahmani, M.; Shirzad, H.; Rafieian, S.; Rafieian-Kopaei, M. Silybum marianum: Beyond Hepatoprotection. J. Evid. Based Complement. Altern. Med. 2015, 20, 292-301. [CrossRef] [PubMed]

158. Kazazis, C.; Geladari, E.; Trigkidis, K.; Vallianou, N.G. Milk Thistle: New Perspectives for an Old Remedy. Curr. Top. Nutraceut. Res. 2016, 14, 103-107.

159. Kenny, O.M.; McCarthy, C.M.; Brunton, N.P.; Hossain, M.B.; Rai, D.K.; Collins, S.G.; Jones, P.W.; Maguire, A.R.; O'Brien, N.M. Anti-inflammatory properties of potato glycoalkaloids in stimulated Jurkat and Raw 264.7 mouse macrophages. Life Sci. 2013, 92, 775-782. [CrossRef]

160. Visvanathan, R.; Jayathilake, C.; Chaminda Jayawardana, B.; Liyanage, R. Health-beneficial properties of potato and compounds of interest: Health-beneficial properties of potato. J. Sci. Food Agric. 2016, 96, 4850-4860. [CrossRef]

161. Basilicata, M.G.; Pepe, G.; Rapa, S.F.; Merciai, F.; Ostacolo, C.; Manfra, M.; Di Sarno, V.; Autore, G.; De Vita, D.; Marzocco, S.; et al. Anti-Inflammatory and Antioxidant Properties of Dehydrated Potato-Derived Bioactive Compounds in Intestinal Cells. Int. J. Mol. Sci. 2019, 20, 6087. [CrossRef] [PubMed]

162. Popovych, V.; Koshel, I.; Malofiichuk, A.; Pyletska, L.; Semeniuk, A.; Filippova, O.; Orlovska, R. A randomized, open-label, multicenter, comparative study of therapeutic efficacy, safety and tolerability of BNO 1030 extract, containing marshmallow root, chamomile flowers, horsetail herb, walnut leaves, yarrow herb, oak bark, dandelion herb in the trea. Am. J. Otolaryngol 2019, 40, 265-273. [CrossRef] [PubMed]

163. Fatima, T.; Bashir, O.; Naseer, B.; Hussain, S.Z. Dandelion: Phytochemistry and clinical potential. J. Med. Plants Stud. 2018, 6, 198-202.

164. Jin, Y.R.; Jin, J.; Piao, X.X.; Jin, N.G. The effect of Taraxacum officinale on gastric emptying and smooth muscle motility in Rodents. Neurogastroenterol. Motil. 2011, 23. [CrossRef]

165. Martinez, M.; Poirrier, P.; Chamy, R.; Prüfer, D.; Schulze-Gronover, C.; Jorquera, L.; Ruiz, G. Taraxacum officinale and related species-An ethnopharmacological review and its potential as a commercial medicinal plant. J. Ethnopharmacol. 2015, 169, 244-262. [CrossRef]

166. González-Castejón, M.; Visioli, F.; Rodriguez-Casado, A. Diverse biological activities of dandelion. Nutr. Rev. 2012, 70, 534-547. [CrossRef]

167. Schütz, K.; Carle, R.; Schieber, A. Taraxacum-A review on its phytochemical and pharmacological profile. J. Ethnopharmacol. 2006, 107, 313-323. [CrossRef]

168. Lans, C.; Turner, N.; Khan, T.; Brauer, G.; Boepple, W. Ethnoveterinary medicines used for ruminants in British Columbia, Canada. J. Ethnobiol. Ethnomed. 2007, 3, 11. [CrossRef]

169. Ayrle, H.; Mevissen, M.; Kaske, M.; Nathues, H.; Gruetzner, N.; Melzig, M.; Walkenhorst, M. Medicinal plants-Prophylactic and therapeutic options for gastrointestinal and respiratory diseases in calves and piglets? A systematic review. BMC Vet. Res. 2016, 12, 89. [CrossRef]

170. Jarić, S.; Mitrović, M.; Pavlović, P. Review of Ethnobotanical, Phytochemical, and Pharmacological Study of Thymus serpyllum L. Evid. Based Complement. Altern. Med. 2015, 2015. [CrossRef]

171. Salehi, B.; Prakash Mishra, A.; Shukla, I.; Sharifi-Rad, M.; Del Mar Contreras, M.; Segura-Carretero, A.; Fathi, H.; Nasri Nasrabasi, N.; Kobarfard, F.; Sharifi-Rad, J. Thymol, Thyme, and Other Plant Sources: Health and Potential Uses. Phyther. Res. 2018, 32, 1688-1706. [CrossRef] [PubMed]

172. Shakeri, F.; Ghorani, V.; Saadat, S.; Gholamnezhad, Z.; Boskabady, M.H. The stimulatory effects of medicinal plants on $\beta 2$-adrenoceptors of tracheal smooth muscle. Iran. J. Allergy, Asthma Immunol. 2019, 18, $12-26$. [CrossRef]

173. Asgarpanah, J.; Mohajerani, R. Phytochemistry and pharmacologic properties of Urtica dioica L. J. Med. Plants Res. 2012, 6, 5714-5719. [CrossRef]

174. Joshi, B.C.; Mukhija, M.; Kalia, A.N. Pharmacognostical review of Urtica dioica L. Int. J. Green Pharm. 2014, 8, 201-209. [CrossRef]

175. Ahmed KK, M.; Parsuraman, S. Urtica dioica L., (Urticaceae): A stinging nettle. Syst. Rev. Pharm. 2014, 5, 6-8. [CrossRef]

176. Kregiel, D.; Pawlikowska, E.; Antolak, H. Urtica spp.: Ordinary Plants with Extraordinary Properties. Molecules 2018, 23, 1664. [CrossRef] 
177. Deng, H.W.; Tian, Y.; Zhou, X.J.; Zhang, X.M.; Meng, J. Effect of Bilberry Extract on Development of Form-Deprivation Myopia in the Guinea Pig. J. Ocul. Pharmacol. Ther. 2016, 32, 196-202. [CrossRef]

178. Gizzi, C.; Belcaro, G.; Gizzi, G.; Feragalli, B.; Dugall, M.; Luzzi, R.; Cornelli, U. Bilberry extracts are not created equal: The role of non anthocyanin fraction. Discovering the "dark side of the force" in a preliminary study. Eur. Rev. Med. Pharmacol. Sci. 2016, 20, 2418-2424.

179. Matsunaga, N.; Imai, S.; Inokuchi, Y.; Shimazawa, M.; Yokota, S.; Araki, Y.; Hara, H. Bilberry and its main constituents have neuroprotective effects against retinal neuronal damage in vitro and in vivo. Mol. Nutr. Food Res. 2009, 53, 869-877. [CrossRef]

180. Ogawa, K.; Tsuruma, K.; Tanaka, J.; Kakino, M.; Kobayashi, S.; Shimazawa, M.; Hara, H. The Protective Effects of Bilberry and Lingonberry Extracts against UV Light-Induced Retinal Photoreceptor Cell Damage in Vitro. J. Agric. Food Chem. 2013, 61, 10345-10353. [CrossRef]

181. Ogawa, K.; Kuse, Y.; Tsuruma, K.; Kobayashi, S.; Shimazawa, M.; Hara, H. Protective effects of bilberry and lingonberry extracts against blue light-emitting diode light-induced retinal photoreceptor cell damage in vitro. BMC Complement. Altern. Med. 2014, 14, 120. [CrossRef] [PubMed]

182. Ozawa, Y.; Kawashima, M.; Inoue, S.; Inagaki, E.; Suzuki, A.; Ooe, E.; Kobayashi, S.; Tsubota, K. Bilberry extract supplementation for preventing eye fatigue in video display terminal workers. J. Nutr. Health Aging 2015, 19, 548-554. [CrossRef] [PubMed]

183. Szajdek, A.; Borowska, E.J. Bioactive Compounds and Health-Promoting Properties of Berry Fruits: A Review. Plant. Foods Hum. Nutr. 2008, 63, 147-156. [CrossRef] [PubMed]

184. Wang, Y.; Zhao, L.; Lu, F.; Yang, X.; Deng, Q.; Ji, B.; Huang, F.; Kitts, D.D. Retinoprotective effects of bilberry anthocyanins via antioxidant, anti-inflammatory, and anti-apoptotic mechanisms in a visible light-induced retinal degeneration model in pigmented rabbits. Molecules 2015, 20, 22395-22410. [CrossRef]

185. Canter, P.H.; Ernst, E. Anthocyanosides of Vaccinium myrtillus (bilberry) for night vision-A systematic review of placebo-controlled trials. Surv. Ophthalmol. 2004, 49, 38-50. [CrossRef]

186. Persson, I.A.-L.; Persson, K.; Andersson, R.G.G. Effect of Vaccinium myrtillus and Its Polyphenols on Angiotensin-Converting Enzyme Activity in Human Endothelial Cells. J. Agric. Food Chem. 2009, 2009, 4626-4629. [CrossRef]

187. Ştefănescu, B.E.; Szabo, K.; Mocan, A.; Crişan, G. Phenolic Compounds from Five Ericaceae Species Leaves and Their Related Bioavailability and Health Benefits. Molecules 2019, 24, 2046. [CrossRef]

188. Davidson, E.; Zimmermann, B.F.; Jungfer, E.; Chrubasik-Hausmann, S. Prevention of Urinary Tract Infections with Vaccinium Products. Phyther. Res. 2014, 28, 465-470. [CrossRef]

189. Abdellah, S.A.; Berlin, A.; Blondeau, C.; Guinobert, I.; Guilbot, A.; Beck, M.; Duforez, F. A combination of Eschscholtzia californica Cham. and Valeriana officinalis L. extracts for adjustment insomnia: A prospective observational study. J. Tradit. Complement. Med. 2020, 10, 116-123. [CrossRef]

190. Aliakbari, F.; Rafieian, M. The effectiveness of Valeriana officinalis on sleep disturbance in patients with chronic heart failure. Int. J. Pharm. Investig. 2018, 8, 145-150. [CrossRef]

191. Bent, S.; Padula, A.; Moore, D.; Patterson, M.; Mehling, W. Valerian for Sleep: A Systematic Review and Meta-Analysis. Am. J. Med. 2006, 119, 1005-1012. [CrossRef] [PubMed]

192. Mineo, L.; Concerto, C.; Patel, D.; Mayorga, T.; Paula, M.; Chusid, E.; Aguglia, E.; Battaglia, F. Valeriana officinalis Root Extract Modulates Cortical Excitatory Circuits in Humans. Neuropsychobiology 2017, 75, 46-51. [CrossRef] [PubMed]

193. Murphy, K.; Kubin, Z.J.; Shepherd, J.N.; Ettinger, R.H. Valeriana officinalis root extractshavepotentanxiolyticeffectsin laboratoryrats. Phytomedicine 2010, 17, 674-678. [CrossRef] [PubMed]

194. Murti, K.; Kaushik, M.; Sangwan, Y.; Kaushik, A. Pharmacological Properties of Valeriana officinalis-A Review. Pharmacologyonline 2011, 3, 641-646.

195. Nandhini, S.; Narayanan, K.B.; Ilango, K. Valeriana officinalis: A Review of its Traditional Uses, Phytochemistry, and Pharmacology. Asian J. Pharm. Clin. Res. 2018, 11, 36. [CrossRef]

196. Leach, M.J.; Page, A.T. Herbal medicine for insomnia: A systematic review and meta-analysis. Sleep Med. Rev. 2015, 24, 1-12. [CrossRef]

197. Kurti, F.; Giorgi, A.; Beretta, G.; Mustafa, B.; Gelmini, F.; Testa, C.; Angioletti, S.; Giupponi, L.; Zilio, E.; Pentimalli, D.; et al. Chemical composition, antioxidant and antimicrobial activities of essential oils of different Pinus species from Kosovo. J. Essent. Oil Res. 2019, 31, 263-275. [CrossRef] 
198. Venditti, A.; Serrilli, A.M.; Vittori, S.; Papa, F.; Maggi, F.; Di Cecco, M.; Ciaschetti, G.; Bruno, M.; Rosselli, S.; Bianco, A. Secondary metabolites from Pinus mugo Turra subsp. mugo growing in the Majella National Park (Central Apennines, Italy). Chem. Biodivers. 2013, 10, 2091-2100. [CrossRef]

199. Aziz, M.A.; Adnan, M.; Khan, A.H.; Shahat, A.A.; Al-Said, M.S.; Ullah, R. Traditional uses of medicinal plants practiced by the indigenous communities at Mohmand Agency, FATA, Pakistan. J. Ethnobiol. Ethnomed. 2018, 14, 2. [CrossRef]

200. Pignatti, S.; Guorino, R.; La Rosa, M. Flora d'Italia, 2nd ed.; Edagricole, Ed.; New Business Media: Bologna, Italy, 2017.

201. Signorini, M.A.; Lombardini, C.; Bruschi, P.; Vivona, L. Conoscenze etnobotaniche e saperi tradizionali nel territorio di San Miniato (Pisa). Atti. Soc. Tosc. Sci. Nat. Mem. Series B 2008, 1, 65-83.

202. Trotter, R.T.; Logan, M.H. Informant Consensus: A New Approach for Identifying Potentially Effective Medicinalplants. In Plants in Indigenous Medicine E Diet: Biobehavioral Approaches; Etkin, N.L., Ed.; Redgrave Publishing Company: Bedford Hills/New York, NY, USA, 1986; pp. 91-112.

203. Friedman, J.; Zohara, Y.; Amotz, D.; Palewitch, D. A preliminary classification of the healing potential of medicinal plants, based on a rational analysis of an ethnopharmacological field survey among Bedouins in the Negev Desert, Israel. J. Ethnopharmacol. 1986, 16, 275-278. [CrossRef]

204. Mustafa, B.; Hajdari, A.; Pieroni, A.; Pulaj, B.; Koro, X.; Quave, C.L. A cross-cultural comparison of folk plant uses among Albanians, Bosniaks, Gorani and Turks living in south Kosovo. J. Ethnobiol. Ethnomed. 2015, 11. [CrossRef]

205. Guarrera, P.M. Traditional phytotherapy in Central Italy (Marche, Abruzzo, and Latium). Fitoterapia 2005, 76, 1-25. [CrossRef] [PubMed]

206. Lucchetti, L.; Zitti, S.; Taffetani, F. Ethnobotanical uses in the Ancona district (Marche region, Central Italy). J. Ethnobiol. Ethnomed. 2019, 15, 9. [CrossRef] [PubMed]

207. Silva, P.T.M.; Silva, M.A.F.; Silva, L.; Seca, A.M.L. Ethnobotanical knowledge in sete cidades, azores archipelago: First ethnomedicinal report. Plants 2019, 8, 256. [CrossRef] [PubMed]

208. Grabherr, G. Biodiversity in the high ranges of the Alps: Ethnobotanical and climate change perspectives. Glob. Environ. Chang. 2009, 19, 167-172. [CrossRef]

209. Abbet, C.; Mayor, R.; Roguet, D.; Spichiger, R.; Hamburger, M.; Potterat, O. Ethnobotanical survey on wild alpine food plants in Lower and Central Valais (Switzerland). J. Ethnopharmacol. 2014, 151, 624-634. [CrossRef] [PubMed]

210. Aro, A.A.; Perez, M.O.; Vieira, C.P.; Esquisatto, M.A.M.; Rodrigues, R.A.F.; Gomes, L.; Pimentel, E.R. Effect of Calendula officinalis cream on achilles tendon healing. Anat. Rec. 2015, 298, 428-435. [CrossRef]

211. Grosu, E.; Ichim, M.C. Turning Meadow Weeds Into Valuable Species for the Romanian Ethnomedicine While Complying with the Environmentally Friendly Farming Requirements of the European Union's Common Agricultural Policy. Front. Pharmacol. 2020, 11, 1-12. [CrossRef]

212. Zheleva-Dimitrova, D.; Zhelev, I.; Dimitrova-Dyulgerova, I. Antioxidant Activity of Some Carduus Species Growing in Bulgaria. Free Radic. Antioxid. 2011, 1, 15-20. [CrossRef]

213. Street, R.A.; Sidana, J.; Prinsloo, G. Cichorium intybus: Traditional Uses, Phytochemistry, Pharmacology, and Toxicology. Evid. Based Complement. Altern. Med. eCAM 2013, 2013, 579319. [CrossRef] [PubMed]

214. Satmbekova, D.; Srivedavyasasri, R.; Orazbekov, Y.; Omarova, R.; Datkhayev, U.; Ross, S.A. Chemical and biological studies on Cichorium intybus L. Nat. Prod. Res. 2018, 32, 1343-1347. [CrossRef] [PubMed]

215. Subiza, J.L.; Subiza, J.L.; Alonso, M.; Hinojosa, M.; Garcia, R.; Jerez, M.; Subiza, E. Allergic conjunctivitis to chamomile tea. Ann. Allergy 1990, 65, 127-132. [PubMed]

216. Srivastava, J.K.; Gupta, S. Extraction, characterization, stability and biological activity of flavonoids isolated from chamomile flowers. Mol. Cell. Pharmacol. 2009, 1, 138-147. [CrossRef]

217. Shin, S.; Lee, J.-A.; Kim, M.; Kum, H.; Jung, E.; Park, D. Anti-Glycation Activities of Phenolic Constituents from Silybum marianum (Milk Thistle) Flower in Vitro and on Human Explants. Molecules 2015, 20, 3549-3564. [CrossRef]

218. Kashiwada, Y.; Takanaka, K.; Tsukada, H.; Miwa, Y.; Taga, T.; Tanaka, S.; Ikeshiro, Y. Sesquiterpene Glucosides From Anti-Leukotriene B4 Release Fraction of Taraxacum officinale. J. Asian Nat. Prod. Res. 2001, 3, 191-197. [CrossRef]

219. Sahu, N.; Arya, K. Ethnobotanical and ethnopharmacological activites of Artemisia nilagirica, Lyonia ovalifolia, Sarcococca saligna and Taraxacum officinale. J. Chem. Inf. Model. 2017, 8, 4818-4825. [CrossRef] 
220. Park, C.M.; Park, J.Y.; Noh, K.H.; Shin, J.H.; Song, Y.S. Taraxacum officinale Weber extracts inhibit LPS-induced oxidative stress and nitric oxide prodction via the NF- KB modulation in RAW 264,7 cells. J. Ethnopharmacol. 2011, 133, 834-842. [CrossRef]

221. Azman, N.A.M.; Skowyra, M.; Muhammad, K.; Gallego, M.G.; Almajano, M.P. Evaluation of the antioxidant activity of Betula pendula leaves extract and its effects on model foods. Pharm. Biol. 2017, 55, 912-919. [CrossRef]

222. Pavlovic, M.; Kovacevic, N.; Tzakou, O.; Couladis, M. The essential oil of Valeriana officinalis L. s.l. growing wild in western serbia. J. Essent. Oil Res. 2004, 16, 397-399. [CrossRef]

223. Fernandez, A.; Edwin Cock, I. The Therapeutic Properties of Juniperus communis L.: Antioxidant Capacity, Bacterial growth Inhibition, Anticancer Activity and Toxicity. Pharmacogn. J. 2016, 8, 273-280. [CrossRef]

224. Al-Snafi, A.E. Medical Importance of Juniperus communis-A Review. Indo Am. J. Pharm. Sci. 2018, 5, 1779-1792. [CrossRef]

225. Cioanca, O.; Hancianu, M.; Mihasan, M.; Hritcu, L. Anti-acetylcholinesterase and Antioxidant Activities of Inhaled Juniper Oil on Amyloid Beta (1-42)-Induced Oxidative Stress in the Rat Hippocampus. Neurochem. Res. 2015, 40, 952-960. [CrossRef] [PubMed]

226. Raudone, L.; Vilkickyte, G.; Pitkauskaite, L.; Raudonis, R.; Vainoriene, R.; Motiekaityte, V. Antioxidant Activities of Vaccinium vitis-idaea L. Leaves within Cultivars and Their Phenolic Compounds. Molecules 2019, 24, 844. [CrossRef] [PubMed]

227. Mirzaee, F.; Hosseini, A.; Jouybari, H.B.; Davoodi, A.; Azadbakht, M. Medicinal, biological and phytochemical properties of Gentiana species. J. Tradit. Complement. Med. 2017, 7, 400-408. [CrossRef] [PubMed]

228. Rostami, H.; Kazemi, M.; Shafiei, S. Antibacterial activity of Lavandula officinalis and Melissa officinalis against some human pathogenic bacteria. Asian J. Biochem. 2012, 7, 133-142. [CrossRef]

229. Mori, H.-M.; Kawanami, H.; Kawahata, H.; Aoki, M. Wound healing potential of lavender oil by acceleration of granulation and wound contraction through induction of TGF- $\beta$ in a rat model. BMC Complement. Altern. Med. 2016, 16, 144. [CrossRef]

230. Miraj, S.; Rafieian-Kopaei, M.; Kiani, S. Melissa officinalis L: A Review Study With an Antioxidant Prospective. J. Evid. Based. Complementary Altern. Med. 2017, 22, 385-394. [CrossRef]

231. Ahmad, M.; Sultana, S.; Fazl-i-Hadi, S.; ben Hadda, T.; Rashid, S.; Zafar, M.; Khan, M.; Khan, M.P.; Yaseen, G. An Ethnobotanical study of Medicinal Plants in high mountainous region of Chail valley (District Swat Pakistan). J. Ethnobiol. Ethnomed. 2014, 10, 36. [CrossRef]

232. Teweldemedhin, M.; Gebreyesus, H.; Atsbaha, A.H.; Asgedom, S.W.; Saravanan, M. Bacterial profile of ocular infections: A systematic review. BMC Ophthalmol. 2017, 17, 1-9. [CrossRef]

233. Kerkoub, N.; Panda, S.K.; Yang, M.-R.; Lu, J.-G.; Jiang, Z.-H.; Nasri, H.; Luyten, W. Bioassay-Guided Isolation of Anti-Candida Biofilm Compounds From Methanol Extracts of the Aerial Parts of Salvia officinalis (Annaba, Algeria). Front. Pharmacol. 2018, 9, 1418. [CrossRef] [PubMed]

234. Sakkas, H.; Papadopoulou, C. Antimicrobial Activity of Basil, Oregano, and Thyme Essential Oils. J. Microbiol. Biotechnol. 2017, 27, 429-438. [CrossRef] [PubMed]

235. Dall'Acqua, S.; Viola, G.; Giorgetti, M.; Loi, M.C.; Innocenti, G. Two new sesquiterpene lactones from the leaves of Laurus nobilis. Chem. Pharm. Bull. 2006, 54, 1187-1189. [CrossRef] [PubMed]

236. Caputo, L.; Nazzaro, F.; Souza, L.; Aliberti, L.; De Martino, L.; Fratianni, F.; Coppola, R.; De Feo, V. Laurus nobilis: Composition of Essential Oil and Its Biological Activities. Molecules 2017, 22, 930. [CrossRef] [PubMed]

237. Jeambey, Z.; Johns, T.; Talhouk, S.; Batal, M. Perceived health and medicinal properties of six species of wild edible plants in north-east Lebanon. Public Health Nutr. 2009, 12, 1902-1911. [CrossRef]

238. Neha, S.; Ritu, R.; Manju, K.; Birendra, K. A review on biological activities of hydrazone derivatives. Int. J. Pharm. Clin. Res. 2016, 8, 162-166.

239. Ouelbani, R.; Bensari, S.; Mouas, T.N.; Khelifi, D. Ethnobotanical investigations on plants used in folk medicine in the regions of Constantine and Mila (North-East of Algeria). J. Ethnopharmacol. 2016, 194, 196-218. [CrossRef]

240. Pranskuniene, Z.; Ratkeviciute, K.; Simaitiene, Z.; Pranskunas, A.; Bernatoniene, J. Ethnobotanical Study of Cultivated Plants in Kaišiadorys District, Lithuania: Possible Trends for New Herbal Based Medicines. Evid. Based Complement. Altern. Med. 2019, 2019. [CrossRef] 
241. Tsioutsiou, E.E.; Giordani, P.; Hanlidou, E.; Biagi, M.; De Feo, V.; Cornara, L. Ethnobotanical Study of Medicinal Plants Used in Central Macedonia, Greece. Evid. Based Complement. Altern. Med. 2019, 2019. [CrossRef]

242. Vogl, S.; Picker, P.; Mihaly-Bison, J.; Fakhrudin, N.; Atanasov, A.G.; Heiss, E.H.; Wawrosch, C.; Reznicek, G.; Dirsch, V.M.; Saukel, J.; et al. Ethnopharmacological in vitro studies on Austria's folk medicine-An unexplored lore in vitro anti-inflammatory activities of 71 Austrian traditional herbal drugs. J. Ethnopharmacol. 2013, 149, 750-771. [CrossRef]

243. Yang, G.; Lee, K.; Lee, M.-H.H.; Kim, S.-H.H.; Ham, I.-H.H.; Choi, H.-Y.Y. Inhibitory effects of Chelidonium majus extract on atopic dermatitis-like skin lesions in NC/Nga mice. J. Ethnopharmacol. 2011, 138, 398-403. [CrossRef] [PubMed]

244. Baldan, V.; Sut, S.; Faggian, M.; Dalla Gassa, E.; Ferrari, S.; De Nadai, G.; Francescato, S.; Baratto, G.; Dall'Acqua, S. Larix decidua Bark as a Source of Phytoconstituents: An LC-MS Study. Molecules 2017, 22, 1974. [CrossRef] [PubMed]

245. Dar, P.A.; Sofi, G.; Jafri, M.A. Polypodium vulgare Linn. a versatile herbal medicine: A review. Int. J. Pharm. Sci. Res. 2012, 3, 1616-1620. [CrossRef]

246. Naz, S.B.; Chaudhry, M.A.; Rahaman, S.U. Dual receptors blocked mechanism arbitrates smooth muscles relaxant effect of Polypodium vulgare. Bangladesh J. Pharmacol. 2016, 11, 414. [CrossRef]

247. Khan, A.; Siddiqui, A.; Jafri, M.A.; Asif, M. Ethnopharmacological Studies of Polypodium vulgare Linn: A Comprehensive Review. J. Drug Deliv. Ther. 2018, 8, 73-76. [CrossRef]

248. Ghedira, K.; Goetz, P.; Le Jeune, R. Alchemilla vulgaris L.: Alchémille (Rosaceae). Phytothérapie 2012, 10, 263-266. [CrossRef]

249. Caliskan, O. Mediterranean Hawthorn Fruit (Crataegus) Species and Potential Usage. In The Mediterranean Diet: An Evidence-Based Approach; Elsevier: Amsterdam, The Netherlands, 2015; pp. 621-628.

250. Djeddi, S.; Boutaleb, H. Evaluation of antioxidative and antibacterial potentials of Crataegus monogyna Jacq. from Evaluation of antioxidative and antibacterial potentials of Crataegus monogyna Jacq. from Mahouna mountain (Algeria ). J. Adv. Sci. Appl. Eng. 2015, 1, 60-63.

251. Malanga, G.A.; Yan, N.; Stark, J. Mechanisms and efficacy of heat and cold therapies for musculoskeletal injury. Postgrad. Med. 2015, 127, 57-65. [CrossRef]

Sample Availability: Samples of the compounds are not available from the authors.

(C) 2020 by the authors. Licensee MDPI, Basel, Switzerland. This article is an open access article distributed under the terms and conditions of the Creative Commons Attribution (CC BY) license (http://creativecommons.org/licenses/by/4.0/). 